MIKROBIOLOGI PANGAN

Rima Azara, S.TP., MP

Ir. Ida Agustini Saidi., MP

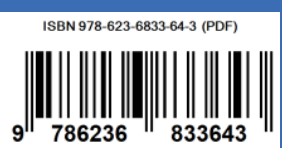

MIKROBIOLOGI PANGAN

Rima Azara, S.TP., MP

Ir. Ida Agustini Saidi., MP 


\title{
BUKU AJAR MIKROBIOLOGI PANGAN
}

\author{
Oleh \\ Rima Azara, S.TP., MP. \\ Ir. Ida Agustini Saidi, MP.
}

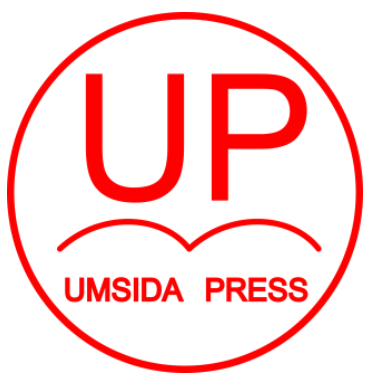

UNIVERSITAS MUHAMMADIYAH SIDOARJO 2020 


\section{BUKU AJAR}

\section{MIKROBIOLOGI PANGAN}

\section{Penulis:}

Rima Azara, S.TP, MP.

Ir. Ida Agustini Saidi, MP.

\section{ISBN :}

978-623-6833-64-3

\section{Editor:}

Prof. Dr. Ir. Andriani Eko Prihatiningrum, MS.

Dr. Ir. Sutarman, MP

\section{Design Sampul dan Tata Letak:}

Mochammad Nasrullah, S.Pd.

Amy Yoga Prajati, S.Kom.

Penerbit:

UMSIDA Press

Anggota IKAPI No. 218/Anggota Luar Biasa/ JTI/2019

Anggota APPTI No. 002018092017

\section{Redaksi}

Universitas Muhammadiyah Sidoarjo

Jl. Mojopahit No 666 B

Sidoarjo, Jawa Timur

Cetakan Pertama, September 2020

(C) Hak Cipta dilindungi undang undang

Dilarang memperbanyak karya tulis ini dengan sengaja, tanpa ijin tertulis dari penerbit. 


\section{KATA PENGANTAR}

Puji syukur kami ucapkan kehadirat Allah SWT, atas rahmat dan karunia-Nya maka Buku Ajar Mikrobiologi Pangan ini dapat terselesaikan dengan baik. Shalawat dan salam selalu kami sampaikan kepada junjungan Nabi Muhammad SAW.

Tim penulis mengucapkan terimakasih kepada:

1. Bapak Dr. Hindarto, S. Kom., MT, Dekan Fakultas Sains dan Teknologi yang telah memberikan arahan dan motivasi kepada penulis dalam menyelesaikan buku ajar ini.

2. Rekan-rekan dosen pengampu Mata Kuliah Mikrobiologi Pangan yang telah berbagi pengalaman dalam mengampu mata kuliah tersebut.

Saran dan kritik sangat penulis harapkan untuk mewujudkan buku ajar Mikrobiologi Pangan yang lebih baik. Terimakasih.

Tim Penulis 


\section{DAFTAR ISI}

HALAMAN SAMPUL .......................................................

KATA PENGANTAR …................................................. ii

DAFTAR ISI ................................................................ii

BAB I PERAN MIKROORGANISME DALAM BAHAN PANGAN

A. Pengertian ......................................................... 1

B. Ruang Lingkup Mikrobiologi Pangan......................... 1

C. Pentingnya Mikrobiologi Pangan ............................... 1

D. Peran Mikroorganisme dalam Bahan Pangan............ 4

E. Kesimpulan.......................................................... 5

F. Latihan Soal .................................................... 6

\section{BAB II SUMBER KONTAMINASI BAHAN PANGAN}

A. Definisi Kontaminasi ............................................. 8

B. Sumber Kontaminasi Bahan Pangan ....................... 8

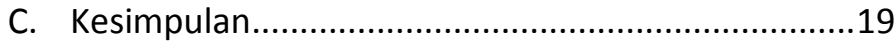

D. Latihan Soal..................................................20

\section{BAB III KERUSAKAN BAHAN PANGAN OLEH}

\section{MIKROORGANISME}

A. Kerusakan oleh Mikroorganisme pada Produk Ikan, Daging, dan Telur ................................................22

B. Kerusakan oleh Mikroorganisme pada Produk Buah dan Sayur .........................................................26

C. Kerusakan oleh mikroorganisme pada Produk Susu dan Produk dari Susu ................................................28

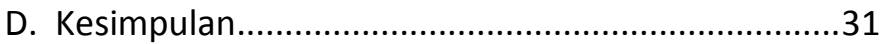

E. Latihan Soal.....................................................31

BAB IV FOODBORNE DISEASE

A. Definisi Foodborne Disease .....................................33

B. Mikroorganisme Penyebab Foodborne Disease ......33 
C. Pencegahan Foodborne Disease ............................38

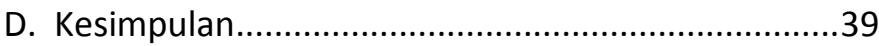

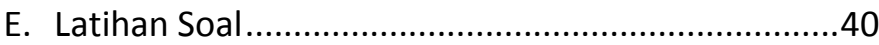

BAB V PRESERVASI BAHAN PANGAN

A. Definisi Preservasi Bahan Pangan ...........................42

B. Macam-Macam Metode Preservasi Bahan Pangan.43

C. Preservasi Bahan Pangan dengan Suhu Tinggi ........45

D. Preservasi Bahan Pangan dengan Suhu Rendah......57

E. Preservasi Bahan Pangan dengan Penurunan Aw ...60

F. Preservasi Bahan Pangan dengan Penurunan $\mathrm{pH}$ dan Asam Organik .....................................................69

G. Preservasi Bahan Pangan dengan Metode Kombinasi (Hurdle Concept) ................................................76

$\mathrm{H}$. Preservasi Bahan Pangan dengan Metode Cleaning dan Sanitasi ................................................................79

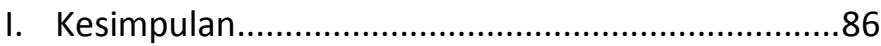

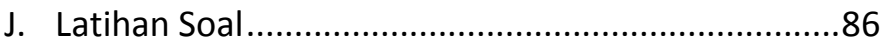

BAB VI PANGAN FERMENTASI
A. Defini Pangan Fermentasi .89
B. Peran Mikroorganisme pada Produk Fermentasi ....90
C. Pangan Fermentasi ...............................................94
D. Kesimpulan......................................................... 100
E. Latihan Soal........................................................ 100

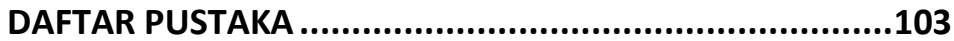

BIODATA PENULIS..............................................107 
BATANG TUBUH DAN

SUB-CAPAIAN PEMBELAJARAN MATA KULIAH

\begin{tabular}{|c|c|}
\hline BAB & Sub-Capaian Pembelajaran Mata Kuliah \\
\hline $\begin{array}{l}\text { BAB I } \\
\text { PERAN } \\
\text { MIKROORGANIS } \\
\text { ME DALAM } \\
\text { BAHAN } \\
\text { PANGAN }\end{array}$ & $\begin{array}{l}\text { 1. Mahasiswa dapat memahami ruang lingkup } \\
\text { Mikrobiologi Pangan. } \\
\text { 2. Mahasiswa juga dapat menjelaskan dan } \\
\text { memberikan contoh pentingnya Mikrobiologi } \\
\text { Pangan. } \\
\text { 3. Mahasiswa mampu menyebutkan Peran } \\
\text { mikroorganisme dalam bahan pangan. }\end{array}$ \\
\hline $\begin{array}{l}\text { BAB II } \\
\text { SUMBER } \\
\text { KONTAMINASI } \\
\text { BAHAN } \\
\text { PANGAN }\end{array}$ & $\begin{array}{l}\text { 1. Mahasiswa mampu menjelaskan tentang Sumber } \\
\text { kontaminasi bahan pangan. } \\
\text { 2. Mahasiswa mampu menjelaskan beberapa metode } \\
\text { pencegahan kontaminasi bahan pangan. }\end{array}$ \\
\hline $\begin{array}{l}\text { BAB III } \\
\text { KERUSAKAN } \\
\text { BAHAN } \\
\text { PANGAN OLEH } \\
\text { MIKROORGANIS } \\
\text { ME }\end{array}$ & $\begin{array}{l}\text { 1. Mahasiswa mampu menjelaskan dan menyebutkan } \\
\text { penyebab kerusakan bahan pangan khususnya ikan, } \\
\text { daging, dan telur. } \\
\text { 2. Mahasiswa mampu menjelaskan dan menyebutkan } \\
\text { penyebab kerusakan bahan pangan khususnya buah } \\
\text { dan sayur. } \\
\text { 3. Mahasiswa mampu menjelaskan dan menyebutkan } \\
\text { penyebab kerusakan bahan pangan khususnya susu } \\
\text { dan produk dari susu. } \\
\text { 4. Mahasiswa mampu menjelaskan ciri-ciri kerusakan } \\
\text { bahan pangan. }\end{array}$ \\
\hline $\begin{array}{l}\text { BAB IV } \\
\text { FOODBORNE } \\
\text { DISEASE }\end{array}$ & $\begin{array}{l}\text { 1. Mahasiswa mampu menjelaskan tentang } \\
\text { Foodborne disease } \\
\text { 2. Mahasiswa mampu menjelaskan mikroorganisme } \\
\text { yang menyebabkan Foodborne disease } \\
\text { 3. Mahasiswa mampu menjelaskan cara pencegahan } \\
\text { Foodborne disease }\end{array}$ \\
\hline
\end{tabular}




\begin{tabular}{|c|c|}
\hline $\begin{array}{l}\text { BAB V } \\
\text { PRESERVASI } \\
\text { BAHAN } \\
\text { PANGAN }\end{array}$ & $\begin{array}{l}\text { 1. Mahasiswa mampu menjelaskan secara garis besar } \\
\text { berbagai metode preservasi bahan pangan sebagai } \\
\text { upaya memperpanjang umur simpan produk pangan. } \\
\text { 2. Mahasiswa mampu menjelaskan mekanisme } \\
\text { pembunuhan mikroba menggunakan panas. } \\
\text { 3. Mahasiswa mampu menjelaskan mekanisme } \\
\text { penghambatan mikroba menggunakan suhu rendah. } \\
\text { 4. Mahasiswa mampu menjelaskan mekanisme } \\
\text { penghambatan mikroba dengan metode penurunan } \\
\text { Aw dan penurunan pH. } \\
\text { 5. Mahasiswa mampu menjelaskan tentang efek } \\
\text { metode kombinasi. } \\
\text { 6. Mahasiswa mampu menjelaskan mekanisme } \\
\text { penghambatan mikroba dengan cleaning dan sanitasi }\end{array}$ \\
\hline $\begin{array}{l}\text { BAB VI } \\
\text { PANGAN } \\
\text { FERMENTASI }\end{array}$ & $\begin{array}{l}\text { 1. Mahasiswa mampu menjelaskan tentang pangan } \\
\text { fermentasi. } \\
\text { 2. Mahasiswa mampu menyebutkan dan menjelaskan } \\
\text { peran mikroorganisme dalam produk fermentasi } \\
\text { tertentu. } \\
\text { 3. Mahasiswa mampu menjelaskan prinsip fermentasi } \\
\text { dari berbagai produk pangan fermentasi. } \\
\text { 4. Mahasiswa mampu menjelaskan proses pembuatan } \\
\text { pangan fermentasi. }\end{array}$ \\
\hline
\end{tabular}




\section{BAB I}

\section{PERAN MIKROORGANISME DALAM BAHAN PANGAN}

A. Pengertian

Peran mikroorganisme dalam bahan pangan sangatlah banyak. Sebelum kita mempelajari tentang peran mikroorganisme, ada baiknya kita mengetahui lebih dalam tentang apa itu ilmu mikrobiologi. Mikrobiologi adalah ilmu yang mempelajari tentang mikroorganisme. Mikroorganisme sendiri merupakan makhluk hidup yang berukuran sangat kecil yang hanya bisa dilihat dengan bantuan alat yaitu mikroskop.

B. Ruang Lingkup Mikrobiologi Pangan

Mikrobiologi Pangan akan belajar mengenai:

a. Mikroba yang berperan dalam pangan

b. Mikroba yang menyebabkan kerusakan pada bahan pangan

c. Sumber kontaminasi bahan pangan

d. Metode yang biasa digunakan untuk menghambat pertumbuhan mikroba

e. Foodborne diseases

f. Pangan fermentasi.

C. Pentingnya Mikrobiologi Pangan

Ada banyak keuntungan jika kita mempelajari tentang ilmu mikrobiologi, diantaranya adalah: 


\section{a. Menentukan kualitas mikrobiologi dari bahan}

pangan dengan teknik yang tepat. Salah satu parameter kualitas dari produk makanan adalah dengan cara mengetahui jumlah mikroba yang ada. Semakin banyak jumlah mikroba yang ada pada bahan pangan itu menandakan kualitas produk yang kurang baik. Sedangkan jika jumlah mikroba dalam bahan pangan sedikit itu menandakan bahwa produk tersebut mempunyai kualitas yang bagus. Analisa yang bisa digunakan untuk menganalisa banyak sedikitnya mikroba yaitu dengan metode TPC (Total Plate Count).

b. Menentukan jenis mikroba pada produk rusak dan mengidentifikasi sumbernya. Belajar tentang ilmu mikrobiologi memungkinkan kita mengetahui jenis mikroba yang menyebabkan kerusakan pada produk tertentu. Misalnya pada produk yang banyak mengandung karobohidrat, umumnya yang mengkontaminasi adalah golongan jamur. Contohnya yaitu tumbuhnya jamur pada roti. Pada produk dengan jumlah protein yang tinggi, umumnya yang menyebabkan kontaminasi adalah jenis bakteri. Seperti pada produk susu, daging, dan lain-lain. Dengan begitu kita bisa mengidentifikasi sumber kontaminasi tersebut. Tentunya dengan metode-metode tertentu. 
c. Mendesain prosedur untuk mengontrol pertumbuhan mikroba pembusuk dan patogen pada bahan pangan. Pertumbuhan mikroba bisa kita hambat dengan cara membuat kondisi lingkungan yang tidak disukai oleh mikroba tersebut.

d. Mendapatkan mikroba spesifik penyebab kerusakan pada bahan pangan sehingga dapat mengatasi masalah yang ada. Ilmu mikrobiologi memungkinkan kita mengetahui mikroba yang menyebabkan bahan makanan rusak dengan berbagai metode yang ada. Misalnya dengan melakukan analisa pewarnaan gram untuk mengetahui mikroba gram positif atau mikroba gram positif. Dan masih banyak lagi metode yang lainnya.

e. Mendesain prosedur sanitasi yang efektif untuk mengontrol pertumbuhan mikroba pembusuk dan patogen pada saat proses produksi. Sanitasi yang baik dibutuhkan untuk menjaga kualitas yang baik pada produk kita. Ilmu mikrobiologi mengajarkan kita berbagai macam sifat mikroba. Baik kondisi yang disukai maupun yang tidak disukai. Dengan kita memahami tentang sifat-sifat mikroba kita bisa merancang bagaimana prosedur 
sanitasi yang efektif, sehingga pertumbuhan mikroba bisa dikontrol.

f. Secara efektif memanfaatkan mikroba untuk menghasilkan produk fermentasi. Ada banyak mikroba yang bermanfaat untuk mengahasilkan produk-produk fermentasi. Misalnya tempe, oncom, tape, tauco, yogurt, nata, kecap, dan lain lain.

g. Mendesain metode untuk menghasilkan starter yang lebih baik yang digunakan untuk pangan fermentasi. Pada saat kita melakukan fermentasi dengan bantuan mikroba tertentu. Kita perlu mengetahui suhu optimum dimana mikroba tersebut tumbuh. IImu mikrobiologi memungkinkan kita untuk mendesain metode untuk menghasilkan starter yang baik dengan mengetahui sifat-sifat yang dimiliki oleh mikroba. Selain sifat dari mikroba tersebut syarat keberhasilan proses fermentasi juga perlu diketahui.

h. Food regulations. Batas minimum dari jumlah mikroba tertentu perlu diketahui untuk menjamin keamanan pangan. 
D. Peran Mikroorganisme dalam Bahan Pangan

Peran mikroorganisme dalam bahan pangan ada dua kategori yaitu peran yang menguntungkan dan peran yang merugikan.

Peran menguntungkan mikroorganisme dalam bahan pangan diantaranya adalah:

a. Mikroorganisme dimanfaatkan untuk mengahasilkan produk fermentasi tertentu.

Contoh produk makanan yang dihasilkan dari proses fermentasi diantaranya adalah tempe, oncom, tape, tauco, yogurt, nata, kecap, dan lainlain.

b. Mikroorganisme juga menghasilkan produk metabolit seperti asam amino, enzim, antibiotik, asam organik, dan lain-lain.

Sedangkan peran merugikan dari mikroorganisme diantaranya adalah:

a. Menyebabkan kerusakan pada bahan makan. Ditandai dengan bahan makanan menjadi berair, berlendir, bau busuk, rasa berubah menjadi asam, timbul jamur, serta terjadi perubahan warna.

b. Menyebabkan beberapa penyakit seperti disentri, tipus, TBC, korela, anthrax, dll.

E. Kesimpulan

- Mikrobiologi adalah ilmu yang mempelajari tentang mikroorganisme.

- Ada banyak keuntungan jika kita mempelajari tentang ilmu mikrobiologi, diantaranya adalah: 
a. Menentukan kualitas mikrobiologi dari bahan pangan dengan teknik yang tepat,

b. Menentukan jenis mikroba pada produk rusak dan mengidentifikasi sumbernya,

c. Mendesain prosedur untuk mengontrol pertumbuhan mikroba pembusuk dan patogen pada bahan pangan,

d. Mendapatkan mikroba spesifik penyebab kerusakan pada bahan pangan sehingga dapat mengatasi masalah yang ada,

e. Mendesain prosedur sanitasi yang efektif untuk mengontrol pertumbuhan mikroba pembusuk dan patogen pada saat proses produksi,

f. Secara efektif memanfaatkan mikroba untuk menghasilkan produk fermentasi,

g. Mendesain metode untuk menghasilkan starter yang lebih baik yang digunakan untuk pangan fermentasi, dan yang terakhir sebagai

h. Food regulations.

- Terdapat keuntungan dan kerugian dari mikroorganisme.

F. Latihan Soal

1. Apa yang saudara ketahui tentang mikrobiologi pangan?

2. Apa saja yang akan saudara pelajari dalam mikrobiologi pangan? 
3. Menurut saudara apakah penting kita mempelajari tentang mikrobiologi pangan? Jika memang penting, jelaskan alasan saudara!

4. Jelaskan peran mikroorganisme yang menguntungkan!

5. Jelaskan peran mikroorganisme yang menurut saudara merugikan! 


\section{Daftar Pustaka}

Adams, M. R. and Maurice O. M. 2008. Food Microbiology:

Third Edition. RSC Publishing: UK

Cano, R.J. dan Colom, J.S. 1986. Microbiology. St. Paul, MN:

West Publishing Company

Frazier, W.C. dan Westhoff, D.C. 1979. Food Microbiology.

New Delhi, India: Tata McGraw Hill Company, Ltd.

Jay, J.M., Martin J.L., and David A.G. 2005. Modern Food

Microbiology: Seventh Edition. Springer: United States of

America

Lim, D. 1990. Microbiology. McGrow-Hill Book, New York

Prescott, L.M., J.P. Harley. \& D.A. Klein. 1999. Microbiology 4th

ed. Mc-Graw Hill Comp, Inc. New York. USA

Dwidjoseputro, D. 2003. Dasar - Dasar Mikrobiologi.

Djambatan. Jakarta

Irianto, K. 2006. Mikrobiologi: Menguak Dunia

Mikroorganisme Jilid 2. CV. Yrama Widya. Bandung

Sumarsih, S., 2003. Mikrobiologi Dasar. Universitas

Pembangunan Nasional Veteran, Yogyakarta

Tortura, G.J., Funke, B.R. dan Case, C.L. 2004. Microbiology.

An Introduction. Menlo Park, CA.: The

Benjamin/Cummings Publishing Company, Inc. 


\section{BAB II \\ SUMBER KONTAMINASI BAHAN PANGAN}

A. Definisi Kontaminasi

Kontaminasi adalah suatu kondisi dimana terjadinya pencamuran oleh sesuatu sehingga menimbulkan kondisi yang tidak diinginkan. Kontaminasi mikroba itu artinya ketika bahan yang kita punya tercampur ataupun tercemar oleh mikroba tertentu yang berakibat pada kerusakan bahan pangan tersebut. Pengetahuan tentang sumber mikroorganisme pada bahan pangan penting dengan tujuan:

- Mengembangkan metode kontrol keberadaan mikroorganisme pada bahan pangan

- Mengembangkan metode untuk membunuh mikroorgaisme

- Menentukan kualitas mikrobiologi

- Menetapkan standard dan spesifikasi makanan dan komponen bahan tambahan.

B. Sumber Kontaminasi Bahan Pangan dan Metode Pencegahannya

Jaringan bagian dalam (internal tissues) pada tanaman baik buah maupun sayur dan juga hewan yang sehat pada dasarnya adalah steril. Tetapi bahan mentah yang sudah mengalami pengolahan (kecuali yang steril) kemungkinan mengandung berbagai tipe kontaminasi dari berbagai 
jenis mikroba diantara kapang, khamir, bakteri, dan virus. Kontaminasi tersebut bisa berasal dari sumber internal maupun sumber eksternal. Sumber eksternal terjadi ketika ada kontak ke bahan pangan waktu produksi sampai konsumsi.

1. Sumber Internal (Alami)

a. Tanaman (Buah dan Sayur)

Sumber mikrooraganisme pada tanaman biasanya terdapat pada bagian permukaan buah, sayuran, pori/mata umbi, dan juga pada biji. Jaringan tanaman bagian dalam pada dasarnya adalah steril kecuali sayuran berpori seperti bawang dan lobak serta sayuran berdaun seperti kubis. Beberapa tanaman memproduksi metabolit antimikroba.

Pada permukaan buah dan sayur, tipe dan jumlah mikroorganismenya bervariasi tergantung pada kondisi tanah, tipe pupuk dan air yang dipakai, serta kualitas udara. Misalnya buah dan sayur yang ditanam pada tanah yang menggunakan pupuk tanpa perlakuan, maka buah dan sayur tersebut dapat terkontaminasi patogen. Dikarenakan pupuk yang digunakan banyak mengandung patogen karena pupuk tersebut tidak diproses terlebih dahulu untuk menghilangkan patogen yang ada pada kotoran. 
Mikroorganisme yang paling banyak ditemui pada buah dan sayur diantaranya adalah:

- Kapang

- Khamir

- Bakteri Asam Laktat (BAL)

- Bakteri dari golongan Pseudomonas, Alcaligenes, Micrococcus, Erwinia, Bacillus, Clostridium, dan Enterobacter.

Jumlah mikroorganisme pada tanaman baik buah dan sayur dapat mengalami peningkatan dikarenakan oleh:

- Penyakit tanaman. Tanaman yang sakit tentu mempunyai jumlah mikroorganisme yang lebih banyak dibandingkan tanaman yang sehat.

- Kerusakan permukaan buah dan sayur yang terjadi baik sebelum, selama, maupun setelah panen dilakukan. Kerusakan buah dan sayur sebelum panen misalnya kerusakan akibat gigitan ulat atau serangga. Kerusakan selama panen misalnya buah yang jatuh pada saat dipanen. Sedangkan kerusakan setelah panen misalnya pada saat pengangkutan buah dan sayuran mengalami benturan.

Buah dan sayur yang rusak mempunyai jumlah mikroorganisme yang banyak dikarenakan buah dan sayur yang rusak akan lebih mudah terkontaminasi oleh 
mikroorganisme yang ada pada udara, sehingga buah dan sayur akan lebih cepat mengalami pembusukan.

- Waktu tunggu yang lama antara panen dan pencucian. Oleh karena itu, perlu penanganan yang cepat setelah panen dilakukan untuk mencegah peningkatan jumlah mikrooganisme.

- Penyimpanan tidak tepat. Misalnya penyimpanan pada ruangan yang kotor jelas akan meningkatkan jumlah mikroorganisme. Selain itu kondisi lingkungan seperti kelembapan udara dan suhu juga berperan dalam peningkatan jumlah mikroorganisme selama masa penyimpanan.

- Kondisi transportasi setelah panen dan sebelum proses. Benturan yang terjadi pada buah selama proses transportasi juga dapat meningkatkan jumlah mikroorganisme dikarenakan banyak buah yang rusak otomatis jumlah mikroorganisme juga semakin banyak.

Jumlah mikroorganisme pada buah dan sayur bisa kita kurangi dengan cara sebagai berikut:

- Menggunakan metode tanam yang tepat yaitu dengan memperhatikan pengaruh penggunaan pupuk dan pemilihan jenis pupuk. Penggunaan pupuk yang sudah diberi 
perlakuan dapat mengurangi jumlah mikroorganisme.

- Mengurangi kerusakan selama panen. Keruskan selama panen misalnya benturan antar buah, atau buah jatuh yang menyebabkan memar perlu dihindari.

- Pencucian cepat dengan kualitas air yang baik untuk menghilangkan tanah, debu, dan kotoran. Kualitas air juga perlu diperhatikan pada saat mencuci hasil panen. Air yang kotor mengandung banyak mikroorganisme sehingga jika air tersebut digunakan untuk proses pencucian maka mikroorganisme pada air akan mengkontaminasi hasil panen tersebut.

- Penyimpanan pada suhu rendah sampai proses. Penyimpanan suhu rendah pada buah dan sayur hasil panen sampai komoditi siap untuk diproses akan mengurangi jumlah mikroorganisme. Suhu rendah dapat menghambat pertumbuhan mikroorganisme tersebut.

b. Hewan

Sumber mikroorganisme pada hewan biasanya banyak ditemui pada bagian kulit hewan, rambut, bulu, saluran pencernaan, saluran urogenital, saluran pernafaan, dan pada saluran susu untuk hewan yang menyusui. Tipe dan 
banyaknya mikroorganisme bervariasi sesuai tipe tanaman dan hewan, lokasi geografis, dan kondisi lingkungan.

Hewan dapat membawa mikroba patogen seperti Salmonella spp., Escherichia coli, Campylobacter jejuni, Yersinia enterocolitica, dan Listeria monocytogenes. Kondisi penyakit, misal mastitis pada sapi, infeksi usus, saluran pernafasan dan uterine maka akan mengubah ekologi mikroflora normal yang ada pada hewan.

Kondisi kandang dan pemeliharaan ternak yang kurang baik, maka akan mengakibatkan kontaminasi fekal pada permukaan badan (kulit, rambut, bulu, dan ambing), kontaminasi air dan makanan ternak.

Mikroflora normal yang terdapat pada ikan dan kerang-kerangan biasanya ditemukan pada kulit dan saluran pencernaan. Patogen yang biasanya ditemukan yaitu Vibrio parahaemolyticus, Vibrio vulnificus, dan Vibrio cholera.

Mikroba pembusuk dan patogen dapat masuk selama produksi dan proses.

- Susu sapi atau susu kambing bisa mengandung mikroba pembusuk dan patogen jika terkontaminasi feses dari hewan penghasil susu tersebut. Hal ini bisa terjadi jika pada waktu pemerahan susu 
tidak memperhatikan sanitasinya dengan baik.

- Kulit telur juga bisa mengandung mikroba pembusuk dan patogen dikarenakan telur terkontaminasi feses dari unggas.

- Daging mengandung banyak mikroba pembusuk dan patogen jika selama pemotongan dan pembersihan, daging tersebut bercampur dengan organ dalam. Dimana organ dalam adalah bagian yang banyak mengandung mikroba. Sehingga mikroba yang ada pada organ dalam akan mengkontaminasi daging.

- Ikan yang masih mengandung organ dalam didalamnya juga bisa mengandung mikroba pembusuk dan patogen.

Mikroba pembusuk dan patogen pada hewan biasanya ditemukan pada bagian kulitnya, rambut, dan bulu. Mikroba tersebut diantaranya adalah Staphylococcus aureus, Micrococcus spp., Corynebacterium spp., kapang dan khamir.

Tindakan pencegahan kontaminasi pada hewan, burung, ikan, dan kerang-kerangan dapat dilakukan dengan cara sebagai berikut:

- Pemeliharaan ternak yang efektif. Kebersihan hewan ternak maupun tempat pemeliharaan harus selalu diperhatikan. 
- Tes kesehatan hewan harus dilakukan secara berkala untuk menjaga kesehatan dari hewan tersebut.

- Penggunaan air dengan kualitas baik selama pemotongan, pencucian, penghilangan bulu, rambut, dan kulit karkas. Penambahan senyawa antimikroba pada air juga bisa dilakukan sebagai upaya pencegahan kontaminasi.

- Cermat dalam penghilangan organ pencernaan, urogenital, dan organ pernafasan.

- Pembersihan yang tepat sebelum perah susu dilakukan. Kemudian susu hasil perah harus segera disimpan pada suhu dingin.

- Telur dikumpulkan segera setelah dikeluarkan. Kemudian dilakukan pencucian. Telur yang sudah bersih selanjutnya disimpan dengan prosedur yang tepat.

- Ikan dipanen dari sumber air tidak terpolusi, sanitasi yang tepat, dan penyimpanan ikan hasil panen harus dilakukan dengan tepat.

2. Sumber Eksternal (Luar)

Ada beberapa sumber eksternal diantaranya adalah dari udara, tanah, air, kotoran, manusia, serangga, peralan, kemasan, dan bahan tambahan. Tipe dan jumlah mikroorganisme bervariasi tergantung derajat sanitasi selama penanganan. 
a. Udara

Mikroorganisme biasanya terdapat di dalam debu, sedangkan udara adalah media perantaranya. Jumlah mikroorganisme pada udara dipengaruhi oleh:

- Kelembapan

- Ukuran dan jumlah partikel debu

- Temperatur dan kecepatan aliran udara

- Ketahanan mikroorganisme pada pengeringan.

Mikroorganisme utama yang terdapat di udara adalah sopra dari Bacillus spp., Clostridium spp., kapang, khamir, dan beberapa bakteri gram positif seperti Micrococcus spp., dan Sarcina spp. Tindakan pengurangan kontaminasi udara dapat dilakukan dengan berbagai cara, diantaranya adalah:

- Menghilangkan sumber kontaminasi udara

- Mengontrol partikel debu, dengan cara memasang filter udara

- Menggunakan teknik Possitive air pressure

- Mengurangi tingkat kelembaban

- Menggunakan cahaya UV. 


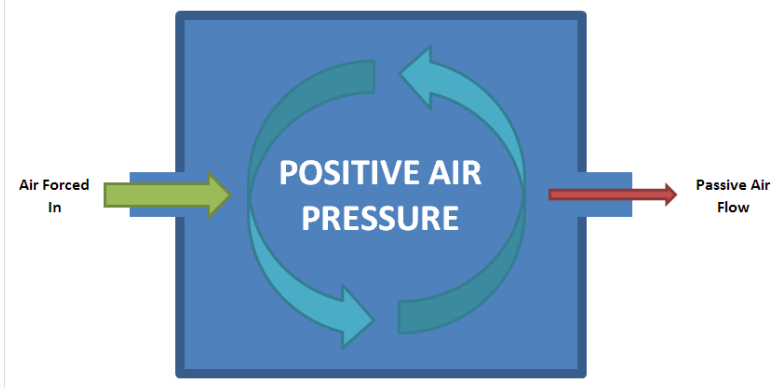

Skema teknik Possitive air pressure

b. Tanah

Mikroorganisme dapat berkembangbiak di dalam tanah. Banyak tipe dari kapang, khamir, dan bakteri yang terdapat dalam tanah. Contoh bakteri yang banyak ditemukan di tanah diantara yaitu, Enterobacter, Pseudomonas, Proteus, Micrococcus, Enterococcus, Bacillus, dan Clostridium. Tanah menjadi sumber patogen bakteri dan virus dikarenakan tanah biasanya terkontaminasi oleh feses. Oleh karena itu, tanah dan kotoran yang menempel pada produk pangan misalnya ikan, produk laut, sayur, umbiumbian, dan lain-lain harus dibuang.

c. Air

Air banyak kita manfaatkan dalam kehidupan sehari-hari. Kebutuhan air biasanya digunakan untuk:

- Irigasi 
- Dunia peternakan memanfaatkan air untuk minuman ternak.

- Dunia perikanan banyak membutuhkan air pada saat panen ataupun produksi produk laut dan ikan-ikanan.

- Dalam dunia industri digunakan untuk mencuci bahan pangan.

- Pada proses produksi biasanya air dibutuhkan saat melakukan proses pasteurisasi, pengalengan, pendinginan, dan sebagai bahan dalam proses pengolahan makanan. Oleh karena itu, kualitas dari air yang digunakan akan mempengaruhi kualitas dari segi kandungan mikroba pada produk pangan tersebut.

- Penyimpanan ikan di dalam es juga membutuhkan air.

- Pencucian dan sanitasi peralatan juga banyak menghabiskan air.

\section{d. Kotoran}

Kotoran adalah sumber kontaminasi bakteri dan virus patogen. Terutama pertanian organik yang menggunakan kotoran hewan sebagai pupuk. Oleh karena itu, penggunaan kotoran sebagai pupuk disarankan agar kotoran yang digunakan sebagai pupuk diberi perlakuan terlebih dahulu. Perlakuan tersebut ditujukan untuk membunuh mikroba patogen yang 
terdapat pada kotoran. Itulah mengapa, buah dan sayur hasil panen harus dicuci setelah dilakukan proses pemanenan.

e. Manusia

Manusia menjadi sumber kontaminasi dikarenakan manusia melakukan kontak dengan bahan pangan di lahan pertanian, lahan peternakan, restoran, jasa catering, dan rumah. Manusia menjadi sumber mikroorganisme patogen. Mikroorganisme patogen tersebut diantaranya adalah Staphylococcus aureus, Salmonella spp, Shigella spp, Escherishia coli, dan mikroorganisme penyebab penyakit Hepatitis A.

Beberapa penyebab manusia menjadi sumber kontaminasi diantaranya adalah tangan yang kotor, kebersihan kurang, pakaian yang dipakai kotor, rambut manusia yang merupakan sumber kontaminasi, manusia sedang sakit atau pembawa bibit penyakit, mengalami luka pada tangan dan kaki, dan lain-lain. Oleh karena itu, pelatihan tentang Personal hygiene perlu dilakukan untuk melatih karyawan paham betul tentang kebersihan diri. Cek kesehatan juga perlu dilakukan secara berkala untuk memastikan karyawan dalam kondisi sehat. Pemeliharan sanitasi sangat diperlukan untuk mencegah terjadinya kontaminasi mikroba yang disebabkan oleh manusia. 
f. Peralatan

Alat mempunyai bentuk dan jenis yang beragam tergantung pada fungsi dan dimana alat tersebut digunakan. Misalkan alat-alat yang digunakan pada saat panen akan berbeda dengan alat yang digunakan pada saat transportasi, pengolahan, dan penyimpanan. Mikroorganisme yang terdapat pada peralatan sangat banyak tipenya. Mikroorganisme tersebut berasal dari udara, bahan baku, air, dan pekerja yang masuk ke peralatan dan pada akhirnya akan mengkontaminasi bahan pangan yang menggunakan peralatan tersebut. Oleh karena itu, penting dilakukan pembersihan dan sanitasi dari peralatan-peralatan tersebut secara rutin.

Mikroba yang biasanya terdapat pada peralatan diantaranya adalah dari golongan Salmonella, Listeria, Escherichia, Enterococcus, Micrococcus, Pseudomonas, Lactobacillus, Leuconostoc, Clostridium, Bacillus, khamir dan kapang.

g. Bahan Tambahan

Bahan tambahan adalah komponen penyusun makanan olahan. Bahan tambahan adalah sumber mikroorganisme pembusuk dan patogen. Jenis yang paling banyak terdapat pada bahan tambahan adalah jenis kapang dan bakteri 
penghasil spora. Bahan tambahan yang mengandung bakteri thermofilik penghasil spora adalah pati, gula, dan tepung. Tindakan untuk mengurangi kontaminasi yang disebabkan oleh bahan tambahan pangan adalah dengan menciptakan kondisi sanitasi yang baik. Dapat pula dengan perlakukan penambahan senyawa antimikroba.

h. Lain-lain

Sumber kontaminasi selain yang sudah dijelaskan sebelumnya, kontaminasi bahan pangan selama proses juga bisa disebabkan oleh sumber kontaminasi lain seperti kemasan atau wadah yang digunakan, serangga, burung, hewan pengerat, binatang peliharaan seperti kucing, anjing, dan lain-lain.

\section{Kesimpulan}

- Kontaminasi adalah suatu kondisi dimana terjadinya pencamuran oleh sesuatu sehingga menimbulkan kondisi yang tidak diinginkan.

- Kontaminasi tersebut bisa berasal dari sumber internal maupun sumber eksternal.

- Termasuk dalam sumber internal yaitu tanaman (buah dan sayur) dan hewan.

- Sedangkan beberapa sumber eksternal diantaranya adalah dari udara, tanah, air, kotoran, manusia, serangga, peralan, kemasan, dan bahan tambahan. 
- Sumber eksternal terjadi ketika ada kontak ke bahan pangan waktu produksi sampai konsumsi. Tipe dan jumlah mikroorganisme bervariasi tergantung derajat sanitasi selama penanganan.

D. Latihan Soal

1. Apa yang saudara ketahui tentang kontaminasi?

2. Terdapat dua macam jenis kontaminasi, yaitu internal dan eksternal. Apa sajakah yang termasuk dalam kontaminasi internal dan eksternal?

3. Manusia merupakan salah satu sumber kontaminasi, bagaimana bisa manusia bisa menjadi sumber kontaminasi? Jelaskan!

4. Pupuk jenis apa yang bagus digunakan untuk tanaman sebagai upaya untuh mencegah kontaminasi?

5. Bagaimana caranya untuk mencegah kontaminasi yang berasal dari peralatan? 


\section{Daftar Pustaka}

Adams, M. R. and Maurice O. M. 2008. Food Microbiology:

Third Edition. RSC Publishing: UK

Cano, R.J. dan Colom, J.S. 1986. Microbiology. St. Paul, MN:

West Publishing Company

Frazier, W.C. dan Westhoff, D.C. 1979. Food Microbiology.

New Delhi, India: Tata McGraw Hill Company, Ltd.

Jay, J.M., Martin J.L., and David A.G. 2005. Modern Food

Microbiology: Seventh Edition. Springer: United States of

America

Lim, D. 1990. Microbiology. McGrow-Hill Book, New York

Prescott, L.M., J.P. Harley. \& D.A. Klein. 1999. Microbiology 4th

ed. Mc-Graw Hill Comp, Inc. New York. USA

Ray, Bibek. 2005. Fundamental Food Microbiology: Third Edition. CRC Press: London

Suriawiria U. 2005. Mikrobiologi Dasar. Jakarta : Papas Sinar Sinanti

Tortura, G.J., Funke, B.R. dan Case, C.L. 2004. Microbiology.

An Introduction. Menlo Park, CA.: The

Benjamin/Cummings Publishing Company, Inc. 


\section{BAB III \\ KERUSAKAN BAHAN PANGAN OLEH \\ MIKROORGANISME}

A. Kerusakan oleh Mikroorganisme pada Produk Ikan, Daging, dan Telur

Ikan, daging, dan telur mudah mengalami kerusakan karena mempunyai gizi yang tinggi dan kandungan air pada bahan yang cukup banyak. Serta mengandung banyak vitamin dan mineral.

1. Ikan

Kerusakan oleh mikroorganisme yang terjadi pada ikan pada umumnya disebabkan oleh kontaminasi bakteri. Aktivitas mikroba dapat menyebabkan berbagai perubahan biokimia dan fisika pada tubuh ikan, yang dapat menyebabkan kebusukan. Faktor kerusakan ikan dipengaruhi oleh:

- Jenis ikan dan peraian ikan ditangkap

- Kondisi ikan ketika ditangkap

- Jumlah kontaminan bakteri pada daging ikan

- Suhu

Ciri-ciri kerusakan pada ikan diantaranya adalah:

- Lendir pada permukaan kulit ikan jumlahnya meningkat, terutama pada bagian insang dan sirip. 
- Terjadi perubahan warna ikan menjadi kusam dan pucat, warna ikan ada yang berubah menjadi kuning kehijauan, kuning, pink, dan coklat. Warna insang memudar berubah dari merah menjadi pink keabu-abuan.

- Perubahan pada tekstur ikan, ikan menjadi lembek, berkurang kekenyalannya, dan daging mudah terlepas.

- Terjadi perubahan bau atau aroma ikan. Bau busuk terjadi karena terbentuknya ammonia, $\mathrm{H}_{2} \mathrm{~S}$ dan senyawa-senyawa berbau busuk lainnya. Perubahan bau busuk (anyir) pada ikan laut lebih cepat dibandingkan ikan air tawar.

- Rasa ikan berubah seperti rasa lumpur. Ketengikan juga terjadi karena ada pemecahan dan oksidasi lemak.

- Mata ikan menyusut dan tenggelam, pupil berkabut, kornea menjadi buram.

Bakteri penyebab kerusakan pada ikan diantaranya adalah Pseudomonas, Acinetobacter, Moraxella, Flavobacterium, Micrococcus, Bacillus, Eschercia, Proteus, Serratia, Sarcina, dan Clostidium. Kontaminan pada ikan olahan seperti ikan asin biasanya disebabkan oleh bakteri halofilik. Sedangkan pada ikan yang diasap disebabkan oleh mikroba jenis kapang.

Kerusakan ikan oleh mikroorganisme dapat dicegah dengan beberapa cara. 
- Penyimpanan suhu dingin.

- Dilakukan proses pengolahan ikan seperti penggaraman, pemindangan, pengeringan, pengasapan, dan lain lain.

- Membuang isi perut dan insang serta dihilangkan lendir-lendirnya.

2. Daging

Mikroorganisme mengkontaminasi daging bisa disebabkan oleh banyak faktor. Diantaranya adalah:

- Terkontaminasi dari organ dalam hewan yang banyak mengandung mikroorganisme

- Kondisi hewan sebelum disembelih, terutama kesehatan dari hewan tersebut

- Tingkat sanitasi selama pemeliharaan dan penyembelihan

- Kecepatan pendinginan daging hasil sembelihan

Tanda daging mengalami kerusakan akibat kontaminasi mikroorganisme diantaranya adalah:

- Permukaan daging menjadi berlendir, akibat kontaminasi dari golongan bakteri dan khamir.

- Terjadi perubahan warna pada daging.

- Perubahan bau pada daging, daging menjadi berbau busuk dan masam. Perubahan bau menjadi busuk karena pemecahan protein dan terbentuknya senyawa-senyawa berbau busuk seperti ammonia, $\mathrm{H}_{2} \mathrm{~S}$, dan senyawa lain-lain. 
- Rasa daging menyimpang menjadi berasa asam. Hal ini dikarenakan ada pertumbuhan bakteri pembentuk asam.

- Terjadi ketengikan yang disebabkan karena pemecahan atau oksidasi lemak.

- Terjadi perubahan penampakan dari daging, seperti adanya bintik hitam ataupun putih dan noda berwarna hijau.

Kerusakan daging oleh mikroorganisme disebabkan oleh bakteri, kapang, maupun khamir. Contoh mikroorganisme tersebut adalah Pseudomonas, Acinetobacter, Alcaligenes, Moraxella, Streptococcus, Leuconostoc, Bacillus, Micrococcus, Lactobacillus, Photobacterium spp, dan Actinomycetes.

Kerusakan pada daging bisa dicegah dengan beberapa cara diantaranya adalah penanganan yang higienis baik pekerja, bangunan, dan peralatan yang digunakan selama proses. Penyimpanan daging juga perlu diperhatikan untuk mencegah kerusakan daging. Daging baiknya disimpan pada suhu beku. Proses pembekuan daging dapat menghambat pertumbuhan mikroba.

3. Telur

Telur merupakan produk yang bisa mengalami kerusakan akibat mikroorganisme. Mikroba dari air, udara, dan kotoran ayam dapat masuk ke dalam telur 
yang utuh melalui pori-pori yang terdapat pada cangkang telur. Tanda-tada kerusakan pada telur diantaranya adalah:

- Bau busuk pada telur, akibat kontaminasi bakteri pembusuk.

- Timbul bintik-bintik berwarna seperti bintik hijau, hitam, dan merah akibat pertumbuhan bakteri pembentuk warna.

- Bulukan akibat adanya pertumbuhan kapang pada telur.

- Terjadi kerusakan pada albumin. Albumin berubah menjadi encer. Biasanya disertai dengan serabut hijau, warna menjadi coklat kehitaman atau keabuan diselimuti warna kemerahan.

- Pada kuning telur juga terjadi perubahan tertentu. Seperti kuning telur yang diselimuti bintik pink mengeras, kuning telur berwarna hitam dan berbau busuk, dan kuning telur berwarna kemerahan.

- Cangkang pada telur juga mengalami beberapa perubahan seperti timbulnya bau apek pada cangkang dan tumbuhnya jamur pada cangkang telur.

Kerusakan pada telur dapat dicegah dengan cara memisahkan telur yang bersih dengan telur yang kotor dan antara telur yang lama dengan telur yang baru. Pencucian telur juga perlu dilakukan ketika akan 
disimpan pada suhu dingin. Penyimpanan telur yang disarankan yaitu pada suhu $12-15{ }^{\circ} \mathrm{C}$ dan pada kelembapan $70-80 \%$. Ruang penyimpanan telur juga harus jauh dari benda-benda yang berbau tajam seperti bawang.

Mikroorganisme penyebab kerusakan pada telur diantaranya adalah beberapa bakteri seperti Pseudomonas flourence, Aeromonas, dan Serratia. Beberapa jenis jamur juga ada yang menyebabkan kerusakan pada telur. Jamur yang biasa ditemukan pada telur yang rusak diantaranya adalah Penicillum, Alternaria, dan Rhizopus.

B. Kerusakan oleh Mikroorganisme pada Produk Buah dan Sayur

Buah dan sayur adalah bahan makanan yang mudah mengalami kerusakan. Kerusakan buah dan sayur sebagaian besar disebabkan oleh kapang dan khamir. Sedangkan bakteri dalam jumlah yang lebih sedikit. Tanda-tanda buah dan sayur yang mengalami kerusakan karena mikroorganisme adalah:

- Tekstur berubah menjadi lunak, lembek, dan berair. Lunak bisa terjadi juga pada bagian batang, yang biasanya disebut busuk batang.

- Terjadi kebusukan berwarna hitam. Biasanya terjadi pada wortel, bit, pir, dan kembang kol.

- Bau berubah menjadi masam.

- Terlihat adanya pertumbuhan kapang yang ditandai dengan munculnya miselium kapang abu-abu, ada 
juga yang berbentuk kapas kecil berbintik hitam. Kapang berwarna putih seperti wol, yang biasanya ditemukan pada sawi dan lobak.

- Permukaan buah muncul spot/bintik hitam. Misalnya pada buah pisang dan alpukat. Ada juga yang muncul bintik coklat kehijauan dan coklat hitam. Misalnya pada buah lemon, peach, dan tomat.

- Terdapat spora kapang berwarna hijau kebiruan. Misalnya terdapat pada buah anggur, bit, dan aprikot. Spora hitam pekat yang biasanya tumbuh pada bawang merah dan putih, buah pir, dan peach.

Mikroba yang mengokontaminasi buah dan sayur diantaranya adalah Erwinia carotovora, Pseudomonas marginalis, Clostridium, Bacillus spp., Botrytis cinerea, Botrytis spp., Rhizopus sp., Rhizopus stolonifer, Colletotrichum lindemuthianium, Alternaria tenuis, Penicillium digitarium, Phytophthora, Bremia, Sclerotinia sclerotiorum, Diplodia, Alternaria, Phomopsis, Fusarium, Aspergillus niger, Alternaria, Ceratostomella, Physalospora, dan lain-lain.

Kerusakan buah dan sayur dapat dicegah dengan beberapa cara, diantaranya adalah:

- Sanitasi yang baik perlu dilakukan pada saat panen, transportasi, dan penyimpanan sebelum dilakukan proses pengolahan. 
- Transportasi harus diperhatikan dengan baik, untuk mencegah kerusakan selama transportasi. Kerusakan buah dan sayur selama transportasi akan memicu tumbuhnya mikroba pada jaringan yang rusak tersebut. Sehingga buah dan sayur cepat mengalami kebusukan.

- Kondisi selama penyimpanan harus diperhatikan, mulai dari suhu dan kelembapan.

- Penanganan pasca panen harus diperhatikan.

- Pencucian buah dan sayur menggunakan air bersih dan mengalir. Penggunaan air yang tidak bersih menyebabkan mikroorganisme yang terdapat pada air akan berpindah pada buah dan sayur. Sehingga, proses pencucian tidak efektif untuk membersihkan buah dan sayur tapi justru memicu kerusakan buah dan sayur tersebut.

C. Kerusakan oleh mikroorganisme pada Produk Susu dan Produk dari Susu

Susu adalah media yang baik bagi pertumbuhan mikroba karena susu mempunyai kandungan air yang tinggi, pH netral, dan kaya akan nutrisi. Oleh karena itu, susu dan produk olahan dari susu seperti mentega, yogurt, susu skim dan susu krim, es krim, susu kental manis, susu yang diuapkan (evaporated milk), susu kering (susu bubuk) dan berbagai macam hasil olahan susu lainnya mudah mengalami kerusakan akibat kontaminasi mikroorganisme. Kerusakan susu dan produk olahannya akibat mikroorganisme ditandai dengan: 
- Pembentukan rasa dan aroma asam pada susu akibat pertumbuhan mikroba dari jenis bakteri asam laktat (BAL).

- Terbentuknya gas pada susu yang ditandai dengan adanya busa pada permukaan susu.

- Rasa susu berubah menjadi getir

- Susu menjadi berlendir, ada juga yang mengalami penggumpalan.

- Susu berubah menjadi bau tengik dan rasa menyimpang karena ada dekomposisi dari lemak yang ada pada susu akibat enzim lipase dari beberapa bakteri.

- Terjadi perubahan warna pada susu akibat tumbuhnya bakteri atau kapang yang menghasilkan pigmen warna tertentu seperti biru, kuning, merah, dan coklat.

- Susu kental manis: kontaminasi mikroba ditandai dengan terbentuknya gas oleh khamir yang memfermentasi sukrosa atau oleh bakteri koliform. Susu kental manis juga bisa mengalami pengentalan dan spot pada permukaan yang merupakan koloni kapang seperti Aspergillus repens dan Penicillium.

Mikroorganisme yang biasanya menyebabkan kerusakan pada susu dan produk dari susu diantaranya adalah Streptococcus lactis, S. Thermophillus, S. Faecalis, S. Lactis, L. Bulgaricus, L. Thermophillus, Bacillus, B. calidolactis, Clostridium, Micrococcus, Alcaligenes 
viscolactis, Aerobacter, Flavobaterium, Serratia, Pseudomonas. Pada susu pasteurisasi mikroba yang menyebabkan kerusakan produk tersebut adalah bakteri termodurik dan pembentuk spora. Dimana mikroba tersebut tidak mati pada saat proses pasteurisasi. Selain itu bisa juga akibat kontaminasi bakteri setelah proses pasteurisasi. Mentega mengalami kontaminasi dengan ditumbuhi Pseudomonas putrefaciens di permukaannya.

Pencegahan kerusakan pada susu dan produk olahannya dapat dilakukan dengan berbagai cara, diantaranya adalah:

- Proses mulai pemerahan susu sampai susu siap dibuat produk olahan tertentu dan kemudian masuk ke penyimpanan harus memperhatikan sanitasi dan hygiene.

- Sterilisasi alat, lingkungan, dan kemasan juga bisa dilakukan untuk mencegah kerusakan susu dan produk olahannya.

- Penyimpanan susu pada suhu rendah. Penyimpanan pada suhu rendah dapat menghambat pertumbuhan mikroorganisme.

- Pasteurisasi adalah proses yang bisa dilakukan untuk membunuh semua mikroba patogen dan beberapa mikroba yang menyebabkan kebusukan pada susu.

- Mengurangi kadar air pada susu. Misalnya dengan dibuat menjadi susu bubuk. Kadar air sangat 
berpengaruh pada daya simpan susu karena air adalah media pertumbuhan mikroba.

- Pengemasan menggunakan teknik kedap udara. Oksigen pada udara dapat menjadi pemicu pertumbuhan mikroba aerobik. Sehingga susu mengalami ketengikan akibat adanya proses oksidasi.

\section{Kesimpulan}

- Bahan makanan banyak mengalami kerusakan akibat mikroorganisme.

- Ikan, daging, dan telur mudah mengalami kerusakan karena mempunyai gizi yang tinggi dan kandungan air pada bahan yang cukup banyak. Serta mengandung banyak vitamin dan mineral.

- Kerusakan buah dan sayur sebagaian besar disebabkan oleh kapang dan khamir. Sedangkan bakteri dalam jumlah yang lebih sedikit.

- Susu dan produk olahan dari susu seperti mentega, yogurt, susu skim dan susu krim, es krim, susu kental manis, susu yang diuapkan (evaporated milk), susu kering (susu bubuk) dan berbagai macam hasil olahan susu lainnya mudah mengalami kerusakan akibat kontaminasi mikroorganisme. 
E. Latihan Soal

1. Jelaskan apa tanda-tanda daging dan susu mengalami kerusakan akibat terkontaminasi oleh bakteri!

2. Jelaskan bagaimana tanda dari buah dan sayur yang terkontaminasi oleh kapang!

3. Bagaimana cara mencegah kerusakan telur akibat kerusakan oleh mikroorganisme?

4. Bagaimana cara memilih ikan yang segar? Sehingga aman untuk diolah dan dikonsumsi.

5. Pada produk susu dan produk olahan dari susu, jenis mikroorganisme dari jenis apa yang sering menyebabkan kerusakan? 


\section{Daftar Pustaka}

Adams, M. R. and Maurice O. M. 2008. Food Microbiology:

Third Edition. RSC Publishing: UK

Cano, R.J. dan Colom, J.S. 1986. Microbiology. St. Paul, MN:

West Publishing Company

Jay, J.M., Martin J.L., and David A.G. 2005. Modern Food

Microbiology: Seventh Edition. Springer: United States of America

Lim, D. 1990. Microbiology. McGrow-Hill Book, New York

Prescott, L.M., J.P. Harley. \& D.A. Klein. 1999. Microbiology 4th ed. Mc-Graw Hill Comp, Inc. New York. USA

Fardiaz, S. 1989. Mikrobiologi Pangan. Institut Pertanian

Bogor, Bogor, Indonesia: Pusat Antar-Universitas Pangan dan Gizi

Fardiaz, S. 1992. Mikrobiologi Pangan I. Gramedia Pustaka Utama. Jakarta

Frazier, W.C. dan Westhoff, D.C. 1979. Food Microbiology.

New Delhi, India: Tata McGraw Hill Company, Ltd.

Gandjar, Indrawati dan Wellyzar, S. 2006. Mikrobiologi Dasar dan Terapan. Jakarta: Yayasan Obor Indonesia

Gupte, S. 1990. Mikrobiologi Dasar. Terjemahan E.Suryawidjaja : The Short Textbook of Medical Microbiology. Bina rupa Aksara. Jakarta

Hidayat, N. 2006. Mikrobiologi Industri. ANDI: Yogyakarta

Lucke, F.K. 2000. Utilization of Microbes to Process and Preserve Meat. Meat Sci

Tortura, G.J., Funke, B.R. dan Case, C.L. 2004. Microbiology. An Introduction. Menlo Park, CA.: The Benjamin/Cummings Publishing Company, Inc. 


\section{BAB IV \\ FOODBORNE DISEASE}

A. Definisi Foodborne Disease

Foodborne disease adalah penyakit yang disebabkan karena mengkonsumsi makanan yang tercemar oleh mikroba atau toksin yang dihasilkan oleh mikroba tertentu. Ketika membahas tentang foodborne disease kita akan menemui beberapa istilah seperti food intoxication/food poisoning dan food infection.

Food intoxication adalah penyakit yang disebabkan karena kita mengkonsumsi makanan yang mengandung toksin yang dihasilkan oleh mikroba tertentu. Meskipun mikroba dalam makanan tersebut mati tetapi toksinnya tertinggal di dalam makanan dan masuk kedalam tubuh orang yang mengkonsumsi. Contoh mikroba yang menyebabkan food intoxication adalah Staphylococcus aureus. Sedangkan food infection terjadi ketika kita mengkonsumsi makanan yang mengandung mikroba. Kemudian mikroba tersebut masuk ke dalam tubuh orang yang mengkonsumsi dan menyebabkan infeksi. Contoh mikroba yang menyebabkan food infection adalah Salmonella, Campylobacter jejuni, dan Listeria monocytogenes.

B. Mikroorganisme Penyebab Foodborne Disease

1. Staphylococcus aureus 
Keracunana makanan akibat Staphylococcus aureus disebabkan oleh enterotoksin yang dihasilkan. Gejala yang timbul akibat mengkonsumsi bakteri ini yaitu diare dan muntah. Bakteri ini akan mati pada saat makanan diolah dengan menggunakan suhu tinggi, tetapi enterotoksin yang dihasilkan oleh bakteri ini tahan pada suhu $100{ }^{\circ} \mathrm{C}$ selama beberapa menit. Bakteri ini ditemukan pada bahan pangan seperti salad, susu, dan produk berbasis susu.

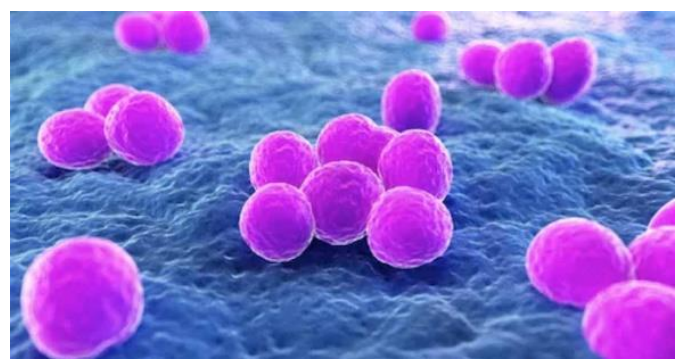

Staphylococcus aureus

\section{Salmonella}

Gejala yang ditimbulkan akibat mengkonsumsi makanan yang tercemar Salmonella yaitu mual, muntah, kram perut, diare, demam, sakit kepala, panas dingin, dan darah di feses. Salmonella berkembang biak pada suhu $5-45^{\circ} \mathrm{C}$. Bakteri ini akan mati saat kita mengolah makanan di atas suhu $70{ }^{\circ} \mathrm{C}$. Namun bakteri ini tidak mati pada saat kita menyimpan makanan di dalam freezer atau lemari pendingin. 


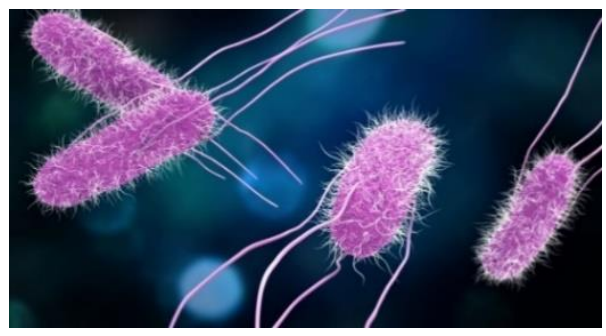

Salmonella

Salmonella biasanya banyak ditemukan pada bagian usus hewan. Oleh karena itu bakteri ini masuk ke dalam tubuh manusia saat kita makan makanan dari binatang yang tidak cukup matang, seperti daging, ayam, serta telur dan produknya.

3. Escherichia coli

Penyakit yang ditimbulkan akibat mengkonsumsi makanan yang tercemar $E$. Coli sering berupa diare yang parah dan berdarah dan kram perut yang menyakitkan, tanpa banyak demam. E. coli dapat masuk ke dalam tubuh manusia terutama melalui konsumsi pangan seperti daging mentah, daging yang dimasak setengah matang, susu mentah, dan cemaran fekal pada air dan pangan. 


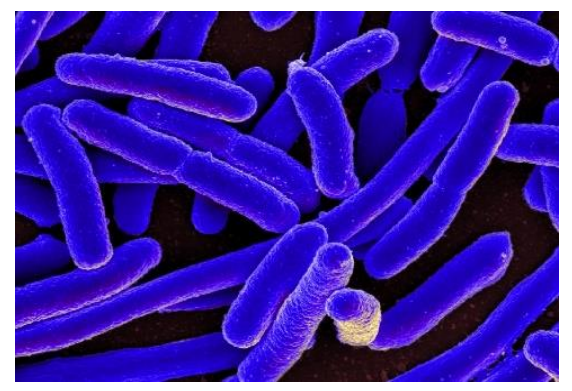

Escherichia coli

\section{Campylobacter jejuni}

Gejala yang ditimbulkan akibat mengkonsumsi makanan yang tercemar $C$. jejuni yaitu sakit perut, demam, diare yang hebat disertai demam, kurang nafsu makan, muntah, dan leukositosis. C. jejuni tumbuh optimum pada suhu $42{ }^{\circ} \mathrm{C}$. Keracunan makanan akibat $C$. jejuni berasal dari bakterinya itu sendiri maupun racun yang dihasilkan oleh bakteri.

C. jejuni hidup di usus burung yang sehat, dan sebagian besar daging unggas mentah memiliki Campylobacter di atasnya. Oleh karena itu, kita perlu menghindari konsumsi daging ayam yang kurang matang, atau makanan lain yang telah terkontaminasi air tetesan dari ayam mentah. $C$. jejuni adalah sumber infeksi yang paling sering. 


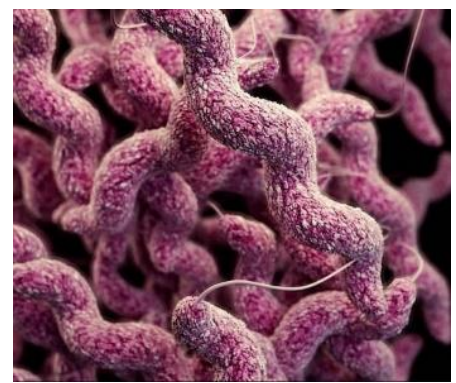

Campylobacter jejuni

5. Listeria monocytogenes

Gejala yang ditimbulkan saat konsumsi makanan yang terkontaminasi L. monocytogenes adalah sakit perut, demam, dan muntah. $L$. monocytogenes adalah baktei gram positif yang hidup di tanah dan air. Listeriosis jarang terjadi pada manusia sehat, tetapi berbahaya bagi orang yang terinfeksi HIV, orang yang sedang kemoterapi, orang tua, wanita hamil, dan anak-anak. Bakteri ini mengkontaminasi susu dan makanan berbasis susu.

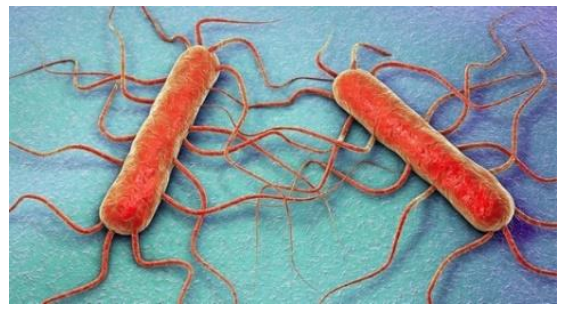

Listeria monocytogenes 


\section{Clostridium perfringens}

Bakteri ini dapat tumbuh cepat pada makanan yang telah dimasak dan menghasilkan enterotoksin yang dapat mengakibatkan penyakit diare. Sayuran dan buah-buahan akan terkontaminasi spora dari Clostridium perfringens melalui tanah. Misalnya pada saat panen buah dan sayur tersebut jatuh ke tanah sehingga terkontaminasi oleh spora yang ada pada tanah. Makanan asal hewan yaitu daging dan olahannya akan terkontaminasi spora dari Clostridium perfringens dari lingkungan atau dari saluran usus hewan yang dipotong pada saat proses pemotongan. Oleh karena itu, sanitasi yang baik pada saat pemotongan hewan sangat diperlukan.

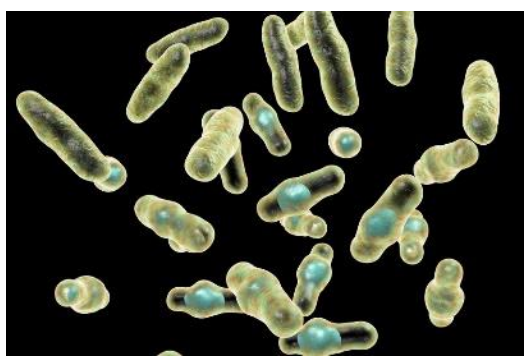

Clostridium perfringens

C. Pencegahan Foodborne Disease

1. Sanitasi

Sanitasi perlu dilakukan pada saat kita akan mengkonsumsi makanan. Budayakan untuk selalu mencuci tangan sebelum makan, menggunakan sabun dan air mengalir. Kontaminasi silang dari 
bahan makanan mentah ke bahan makanan yang sudah siap saji juga sering terjadi. Oleh karena itu, kebiasaan mencuci tangan setelah menangani makanan mentah harus dilakukan sebelum menangani makanan matang.

Ketika kita akan mengkonsumsi buah dan sayur juga harus dilakukan pencucian untuk menghilangkan mikroba yang ada pada buah dan sayur tersebut. Kebersihan air yang digunakan pada proses pencucian juga perlu diperhatikan untuk menghindari kontaminasi mikroba dari air tersebut.

2. Pengolahan bahan pangan

Pengolahan makanan menggunakan suhu tinggi juga diperlukan untuk memastikan mikroba pembusuk maupun mikroba patogen yang ada pada bahan makanan mati. Selain mencegah terjadinya foodborne disease pengolahan makanan juga berfungsi untuk memperpanjang daya simpan bahan makanan itu sendiri.

3. Penyimpanan bahan pangan

Banyak hal yang perlu diperhatikan pada saat kita akan menyimpan bahan pangan. Pertama kita harus memperhatikan beberapa faktor intrinsik yang mempengaruhi pertumbuhan mikroba dalam makanan seperti aktifitas air dan $\mathrm{pH}$. Penyimpanan yang kurang tepat akan berakibat tumbuhnya 
mikroba dengan baik. Hal-hal yang perlu diperhatikan pada saat penyimpanan adalah sebagai berikut:

- Simpan bahan makan mentah pada suhu dingin.

- Makanan panas sebaiknya disimpan pada suhu diatas $60^{\circ} \mathrm{C}$.

- Makanan yang perlu dipanaskan kembali setelah masa penyimpanan, harus segera dipanaskan dan pastikan semua bagian makanan terkena panas.

- Makanan dalam kondisi beku ketika akan digunakan pastikan makanan tersebut dicairkan didalam lemari es atau microwave. Kemudian dimasak sampai matang sempurna.

- Pastikan menyimpan bahan pangan dalam kondisi tertutup.

D. Kesimpulan

- Foodborne disease adalah penyakit yang disebabkan karena mengkonsumsi makanan yang tercemar oleh mikroba atau toksin yang dihasilkan oleh mikroba tertentu.

- Food intoxication adalah penyakit yang disebabkan karena kita mengkonsumsi makanan yang mengandung toksin yang dihasilkan oleh mikroba tertentu.

- Food infection terjadi ketika kita mengkonsumsi makanan yang mengandung mikroba.

- Mikroba yang menyebabkan foodborne disease diantaranya adalah Staphylococcus aureus, 
Salmonella, Escherichia coli, Campylobacter jejuni, Listeria monocytogenes, dan Clostridium perfringens.

- Ada beberapa cara untuk mencegah foodborne disease diantaranya yaitu dengan melakukan sanitasi yang baik, dilakukan proses pengolahan, serta perlu diperhatikan proses penyimpanan yang baik.

E. Latihan Soal

1. Apa yang saudara ketahui tentang foodborne disease?

2. Apa perbedaan antara food intoxication dan food infection?

3. Mikroba apa saja yang sering menyebabkan foodborne disease?

4. Bagaimana caranya agar kita terhindar dari foodborne disease?

5. Jika kita mempunyai makanan kaleng seperti sarden, apa langkah-langkah yang bisa kita lakukan agar terhindar dari foodborene disease? 


\section{Daftar Pustaka}

Adams, M. R. and Maurice O. M. 2008. Food Microbiology:

Third Edition. RSC Publishing: UK

Cano, R.J. dan Colom, J.S. 1986. Microbiology. St. Paul, MN:

West Publishing Company

Frazier, W.C. dan Westhoff, D.C. 1979. Food Microbiology.

New Delhi, India: Tata McGraw Hill Company, Ltd.

Jay, J.M., Martin J.L., and David A.G. 2005. Modern Food

Microbiology: Seventh Edition. Springer: United States of

America

Lim, D. 1990. Microbiology. McGrow-Hill Book, New York Jawetz, Melnick, dan Adelberg's. 2004. Mikrobiologi Kedokteran, Ed 23, Penerbit Buku Kedokteran EGC, Jakarta

Pelczar. J. Michael dan Chan E.C.S. 2006. Dasar-dasar

Mikrobiologi. Universitas Indonesia : Jakarta

Prescott, L.M., J.P. Harley. \& D.A. Klein. 1999. Microbiology 4th

ed. Mc-Graw Hill Comp, Inc. New York. USA

Purwoko,T. 2009. Fisiologi Mikroba. Bumi Aksara. Jakarta

Ryan, KJ; Ray, CG, eds. 2004. Sherris Medical Microbiology (4th ed.). McGraw Hill

Tortura, G.J., Funke, B.R. dan Case, C.L. 2004. Microbiology. An Introduction. Menlo Park, CA.: The Benjamin/Cummings Publishing Company, Inc. 


\section{BAB V \\ PRESERVASI BAHAN PANGAN}

A. Definisi Preservasi Bahan Pangan

Bahan pangan mulai dari buah, sayur, telur, susu, dan daging-dagingan adalah bahan pangan yang mudah mengalami kerusakan (perishable). Kerusakan ini diakibatkan oleh banyak faktor seperti kandungan air dalam bahan pangan itu sendiri maupun dikarenakan kondisi lingkungan. Semakin tinggi kadar air suatu bahan, akan semakin besar kemungkinan kerusakannya baik sebagai akibat aktivitas biologis internal (metabolisme) maupun masuknya mikroba perusak. Mengatasi hal tersebut dibutuhkan upaya untuk mencegah kerusakan bahan pangan sehingga daya simpan bahan pangan meningkat. Upaya untuk mengawetkan bahan pangan dengan mempertahankan sifat fisik dan kimianya disebut dengan pengawetan makanan atau preservasi bahan pangan.

Tujuan kita melakukan preservasi bahan pangan diantaranya adalah sebagi berikut:

- Hal utama yang menjadi tujuan kita melakukan preservasi bahan pangan adalah memperpanjang umur simpan dari produk kita.

- Menghambat ataupun membunuh mikroba penyebab kerusakan bahan pangan. Misalnya dengan penggunaan suhu rendah, suhu tinggi, 
penurunan $\mathrm{pH}$ dan akitivitas air, ataupun penggunaan senyawa antimikroba.

- Menghilangkan mikroba atau memisahkan mikroba yang ada pada bahan pangan kita. Misalnya dengan melakukan proses filtrasi.

- Mencegah kerusakan bahan pangan yang diakibatkan oleh kondisi lingkungan. Seperti misalnya karena serangan hama.

B. Macam-Macam Metode Preservasi Bahan Pangan

Metode preservasi yang paling sederhana yang bisa dilakukan sebelum melakukan metode-metode yang lain yaitu metode preservasi secara fisik. Termasuk dalam metode secara fisik diantaranya adalah sentifugasi, filtrasi, trimming, dan pencucian. Sentrifugasi dapat dilakukan untuk bahan pangan berbentuk cair seperti susu, jus buah, dan sirup. Tujuan dilakukannya sentrifugasi adalah untuk menghilangkan partikel yang tidak diinginkan seperti debu dan partikel yang lainnya. Meskipun dengan sentrifugasi tidak dimaksudkan untuk menghilangkan mikroorganisme, spora, dan bakteri. Tetapi khamir dan jamur bisa dihilangkan dengan sentrifugasi karena mempunyai massa yang lebih berat.

Filtrasi juga digunakan untuk bahan pangan berbentuk cair seperti jus buah, bir, wine, dan air dengan tujuan untuk menghilangkan padatan dan partikel yang tidak diinginkan untuk memberikan efek jernih pada produk tersebut. Filtrasi adalah metode yang tidak menggunakan panas sehingga keuntungan menggunakan 
metode ini adalah rasa alami dan nutrisi pada produk yang tidak tahan panas (seperti vitamin C) bisa dipertahankan. Proses filtrasi bisa juga digunakan sebagai langkah dalam produksi konsentrat jus dengan rasa yang lebih baik dan vitamin yang lebih tinggi. Metode yang sering digunakan adalah metode ultrafiltrasi. Metode ini tergantung pada ukuran pori filter. Filter dengan ukuran pori 0,45-0,7 mm efektif menghilangkan khamir, kapang, dan sebagian besar sel bakteri dan spora dari produk cair.

Trimming merupakan metode yang dilakukan dengan cara kita membuang bagian pada produk pangan yang terlihat mengalami kerusakan oleh mikroorganisme dengan cara memangkasnya. Misalnya menghilangkan kapang yang terlihat pada permukaan kubis. Bisa juga diaplikasikan untuk membuang bagian yang rusak pada keju, roti, sosis terfermentasi, dan produk lain yang ber $\mathrm{pH}$ rendah. Akan tetapi, jika kapang menghasilkan mikrotoksin, pemangkasan tidak bisa memastikan dapat menghilangkan toksin yang tertinggal pada makanan tersebut.

Pencucian juga merupakan salah satu metode preservasi secara fisik. Buah dan sayur dicuci secara teratur untuk menurunkan suhu. Penurunan suhu tersebut berfungsi untuk mengurangi laju metabolisme produk dan pertumbuhan mikroorganisme, serta menghilangkan tanah yang menempel pada produk buah dan sayur. Metode pencucian biasanya juga dilakukan 
untuk pada telur untuk menghilangkan kotoran yang terdapat pada cangkang.

Preservasi bahan pangan harus diperhatikan jenis bahan makanan yang diawetkan, keadaan bahan makanan, cara pengawetan, dan tujuan pengawetan itu sendiri. Metode preservasi yang bisa digunakan untuk mengawetkan bahan pangan diantaranya adalah dengan penggunaan suhu tingi. Misalnya pada proses blansing, pasteurisasi, dan sterilisasi. Selain menggunakan suhu tinggi kita juga bisa menggunakan suhu rendah. Itulah mengapa penyimpanan bahan pangan yang disarankan untuk memperpanjang daya simpan dari bahan pangan tersebut adalah dengan disimpan pada suhu dingin maupun pada suhu beku.

Penurunan Aw (aktifitas air) pada bahan pangan juga efektif untuk menghambat pertumbuhan mikroba. Misalnya dengan melakukan pengeringan pada produk yang kita punya. Penurunan $\mathrm{pH}$ misalnya dengan menambahkan asam organik pada bahan pangan juga bisa menghambat pertumbuhan mikroba sehingga meningkatkan masa simpan dari bahan pangan kita. Selain cara-cara tersebut juga masih banyak cara lain sebagai upaya preservasi bahan pangan.

C. Preservasi Bahan Pangan dengan Suhu Tinggi

Tujuan pemanasan bahan pangan dari aspek mikrobiologis diantaranya adalah:

- Merusak sel vegetatif dan spora mikroba (kapang, khamir, bakteri, virus (termasuk bakteriofag) 
- Membantu inaktivasi enzim dari mikroorganisme ataupun bahan pangan yang tidak dikehendaki.

Contoh: proteinase dan lipase dari mikroorganisme, adalah ezim yang stabil terhadap panas.

- Merusak toksin yg bersal dari mikroorganisme ataupun toksin dari bahan pangan itu sendiri. Pada kasus untuk pemanasan pada toksin yang mempunyai sifat sensitif panas, pemanasan bahan pangan tersebut secukupnya sudah tidak membahayakan, tetapi yang perlu diwaspadai adalah adanya toksin yang stabil terhadap panas.

- Pemanasan pada makanan siap makan mempunyai tujuan untuk mencegah pertumbuhan mikroorganisme patogen dan pembusuk, sehingga dapat mengurangi resiko keracunan. Pemanasan pada makan siap makan dapat dilakukan pada suhu $60^{\circ} \mathrm{C}$.

- Membunuh mikroorganisme kontaminasi sebelum fermentasi dengan tujuan untuk mencegah kegagalan fermentasi.

Mekanisme antimikrobial perlakuan panas yaitu terjadinya kerusakan yang dialami oleh mikroba dan spora. Kerusakannya sendiri ada dua macam yaitu kerusakan letal dan sub letal. Kerusakan letal berarti bahwa mikroba maupun spora mengalami kematian. Sedangkan kerusakan sub letal adalah kerusakan pada sel atau spora, tetapi pada kondisi tertentu sel atau spora 
dapat memperbaiki diri dan memperbanyak diri. Kerusakan sub letal menunjukkan kerusakan pada membran sel, dinding sel, DNA, ribosomal RNA mengalami degradasi, dan beberapa enzim penting mengalami denaturasi.

Perlakuan panas mengakibatkan kerusakan sel mikroba sehingga sel mikroba tersebut kehilangan sifat permeabilitasnya. Hal tersebut menyebabkan keluar masuknya nutrisi menjadi terganggu dan meningkatnya sensitifitas sel terhadap beberapa senyawa dimana pada keadaan normal resisten. Pada akhirnya sel dan spora mengalami kematian. Kematian sel diartikan sebagai kerusakan pada beberapa komponen fungsional dan struktur yang vital.

Selama pemanasan spora bakteri mengalami hal-hal sebagai berikut:

- Kehilangan komponen struktural (from the spore coat)

- Kerusakan pada komponen membran dan dinding

- Tidak mampu menggunakan air untuk hidrasi sebelum germinasi

- Spora tidak mampu bergerminasi dan berkembang.

Faktor - faktor yang mempengaruhi proses pemanasan ada tiga yaitu kondisi bahan pangan, jenis mikroorganisme, dan jenis proses. Faktor-faktor inilah yang menjadi dasar pertimbangan pengembangan dan pemakaian prosedur pemanasan yang efektif pada bahan pangan. 


\section{Kondisi Bahan Pangan}

Termasuk dalam kondisi bahan pangan diantaranya adalah komposisi bahan pangan, aktivitas air (Aw) atau kelembapan, $\mathrm{pH}$, dan kandungan antimikroba.

a. Komposisi Bahan Pangan

Termasuk dalam komposisi bahan pangan tersebut adalah karbohidrat, protein, lemak, dan jumlah bahan yang terlarut. Sebagian besar mikroorganisme, ketahanan terhadap panas tinggi jika komponen tersebut dalam konsentrasi tinggi. Bentuk bahan pangan juga berpengaruh terhadap pengaruh pemanasan terhadap mikroorganisme. Mikroorganisme yang ada pada bahan makanan berbentuk cair akan lebih rentan terhadap panas daripada yang berada pada bahan pangan berbentuk padat. Ukuran partikel juga berpengaruh terhadap efek pemanasan terhadap mikroorganisme. Mikroorganisme yang berada pada bahan pangan dengan ukuran partikel kecil akan lebih rentan terhadapa panas daripada ketika berada pada bahan pangan dengan ukuran partikel yang lebih besar.

b. Aktivitas air (Aw) atau kelembapan

Bahan pangan dengan aktivitas air yang tinggi, ketika diberi perlakukan panas maka mikroorganisme yang berada didalamnya akan 
lebih cepat mati. Hal ini disebabkan karena panas akan lebih cepat menyebar ketika berada pada media yang mengandung air.

c. $\mathrm{pH}$

Bahan pangan dengan $\mathrm{pH}$ rendah ketika dipanaskan akan lebih cepat membunuh mikroorganisme yang ada pada bahan pangan tersebut. Penurunan $\mathrm{pH}$ pada bahan dapat dilakukan dengan menambahkan beberapa jenis asam seperti asam asetat, asam propionat, dan asam laktat. Dimana penggunaan ketiga macam asam tersebut mengakibatkan mikroorganisme lebih rentan terhadap panas daripada jika kita menggunakan asam pospat dan asam sitrat.

d. Kandungan antimikroba

Keberadaan antimikroba akan mempercepat kematian mikroorganisme. Kecepatan kematian tersebut dipengaruhi juga oleh jenis antimikroba.

2. Jenis Mikroorganisme

Termasuk dalam jenis mikroorganisme diantaranya adalah spesies dan strain, fase pertumbuhan, pengaruh panas sebelumnya, dan jumlah awal mikroba.

a. Spesies dan Strain 
Sel vegetatif dari khamir, jamur, dan bakteri lebih sensitif terhadap panas daripada sporanya. Sel mikroorganisme kecuali kelompok thermodurik dan termofilik beserta dengan virus akan mati pada suhu $65{ }^{\circ} \mathrm{C}$ selama 10 menit. Sebagian besar sel bakteri dari kelompok thermodurik dan thermofilik dirusak pada suhu 70-80 ${ }^{\circ} \mathrm{C}$ selama 5-10 menit.

Proses pemanasan untuk merusak spora membutuhkan suhu yang lebih tinggi daripada sel vegetatifnya. Spora khamir dan jamur mati pada suhu $65-70{ }^{\circ} \mathrm{C}$ selama beberapa menit. Tetapi ada juga spora jamur yang dapat bertahan pada suhu $90^{\circ} \mathrm{C}$ selama 4-5 jam.

Suhu yang dibutuhkan untuk membunuh spora bakteri lebih tinggi daripada suhu untuk membunuh spora khamir dan jamur. Spora bakteri yang dipanaskan pada suhu $80-85{ }^{\circ} \mathrm{C}$ selama beberapa menit tidak membunuhnya. Spora bakteri banyak dirusak pada suhu $100{ }^{\circ} \mathrm{C}$ selamat 30 menit, akan tetapi ada juga spora yang tidak rusak sekalipun didihkan pada suhu $100{ }^{\circ} \mathrm{C}$ selama 24 jam. Semua spora rusak pada suhu $121{ }^{\circ} \mathrm{C}$ selama 15 menit, yang biasa kita sebut sterilisasi.

b. Fase pertumbuhan

Pertumbuhan mikroorganisme berpengaruh juga terhadap rentan tidaknya mikroorganisme 
tersebut ketika diberi perlakuan panas. Sel pada fase pertumbuhan eksponensial lebih rentan terhadap panas daripada sel pada fase pertumbuhan stasioner.

c. Pengaruh panas sebelumnya

Jika panas sebelumnya rendah makan mikroorganisme yang ada pada bahan pangan tersebut relatif lebih resisten terhadap panas.

d. Jumlah awal mikroba

Semakin tinggi jumlah awal mikroba maka akan semakin lama waktu yang dibutuhkan untuk membunuh mikrobanya dari level yang seharusnya. Sehingga perlu adanya pengurangan jumlah mikroba awal.

3. Jenis Proses

Suhu spesifik dengan periode waktu tertentu berbanding terbalik. Jadi semakin tinggi suhu maka waktu yang dibutuhkan untuk proses pemanasan semakin pendek. Terjadinya pemanasan secara konduksi dan konveksi pada bahan pangan berbentuk cair lebih cepat daripada bahan pangan berbentuk padat.

Pada proses pemanasan, jenis dan ukuran alat yang digunakan juga berpengaruh terhadap kecepatan panas dalam membunuh mikroorganisme. Kontainer dengan konduktivitas 
tinggi (logam) lebih cepat membunuh mikroorganisme. Kemudian kontainer dengan ukuran kecil akan lebih cepat membunuh mikroorganisme daripada kontainer dengan ukuran besar.

Pemanasan bahan pangan pada suhu yg diberikan untuk waktu spesifik artinya setiap partikel pada bahan pangan harus dipanaskan pada waktu tertentu. Contohnya pada proses pasteurisasi susu, suhu pemanasan adalah $71,6{ }^{\circ} \mathrm{C}$ selama 15 detik. Waktu tersebut disebut dengan holding time, sehingga pemanasan pada suhu kurang dari $71,6{ }^{\circ} \mathrm{C}$ tidak dianjurkan.

Pengawetan menggunakan suhu tinggi merupakan pengawetan dengan cara membunuh mikroorganisme yang ada pada bahan pangan menggunakan panas. Panas tersebut dapat membunuh mikroorganisme dikarenakan terjadi denaturasi protein dan inaktivasi enzim. Pengawetan menggunakan suhu tinggi bervariasi tergantung pada jenis mikroorganisme. Mikroorganisme tersebut termasuk yang sensitif atau yang resisten terhadap panas. Selain jenis mikrooraginsme kondisi lingkungan sebelum pemanasan juga berpengaruh terhadap proses pengawetan menggunakan panas.

Metode pemanasan dibagi menjadi dua yaitu pemanasan suhu rendah dan pemanasan suhu tinggi. Dimana proses pemanasan menggunakan 
suhu dan waktu tertentu. Semakin tinggi suhu maka waktu yang dibutuhkan dalam proses pemasan semakin pendek. Kemudian semakin tinggi jumlah spora maka waktu yang dibutuhkan juga semakin lama.

Metode pemanasan dengan suhu rendah diperuntukkan bagi mikroorganisme yang sensitif terhadap panas. Sehingga mikroba thermodurik kemungkinan masih bertahan. Oleh karena itu, metode pemanasan suhu rendah tidak efektif untuk mikroorganisme thermodurik. Lain halnya dengan metode pemanasan dengan suhu tinggi, metode ini justru diperuntukkan untuk membunuh mikroorganisme thermodurik dan juga spora bakteri pembusuk dan patogen yang paling resisten panas.

a. Pemanasan suhu rendah

Pemanasan suhu rendah contohnya adalah proses pasteurisasi. Metode pemanasan suhu rendah menggunakan suhu kurang dari $100^{\circ} \mathrm{C}$. Metode pemanasan pada suhu rendah akan membunuh semua sel vegetatif dari mikroba patogen dan sebagian besar (90\%) mikroba pembusuk seperti khamir, bakteri, dan virus.

Metode ini juga merusak beberapa enzim yang secara alami ada pada bahan pangan. Contohnya enzim phosphatase yang berada pada susu. Pemanasan dengan suhu rendah memiliki keuntungan yaitu 
kehilangan nutrisi bisa dikurangi sehingga kualitas bahan pangan bisa dipertahankan. Metode ini diperuntukkan bagi mikroorganisme yang sensitif terhadap panas.

Sel mikroba thermodurik dari mikroba pembusuk, dan spora dari mikroba pembusuk dan patogen masih bertahan ketika kita menggunakan metode ini. Oleh karena itu, metode ini membutuhkan kombinasi dengan perlakuan lain untuk mengontrol pertumbuhan mikroorganisme. Kombinasi yang bisa dilakukan misalnya dengan menyimpan bahan pangan pada lemari pendingin, pengemasan juga perlu diperhatikan, mengurangi Aw, dan teknik pengawetan lain yang mungkin bisa dikombinasikan.

Pada metode pemanasan dengan suhu rendah tidak dapat merusak enzim dan toksin yang stabil terhadap panas. Kecuali dipanaskan selama 30 menit atau lebih pada suhu $90{ }^{\circ} \mathrm{C}$ atau lebih. Metode pemanasan suhu rendah dibagi menjadi dua yaitu metode LTLT dan HTST. Penjelasan dari dua metode tersebut dapat dilihat pada Tabel berikut ini. 


\begin{tabular}{llll}
\hline No & Metode & Suhu & Waktu \\
\hline 1 & $\begin{array}{l}\text { LTLT } \\
\text { (Low Temperature }\end{array}$ & $62,8^{\circ} \mathrm{C}$ & 30 \\
& & menit \\
2 & $\begin{array}{l}\text { Long Time) } \\
\text { HTST } \\
\text { (High Temperature } \\
\text { Short Time) }\end{array}$ & $71,1^{\circ} \mathrm{C}$ & 15 \\
& & detik \\
\hline
\end{tabular}

Suhu dan waktu pada proses pemanasan suhu rendah untuk berbagai macam bahan pangan sangat bervariasi. Suhu dan waktu untuk masing-masing bahan pangan dapat dilihat pada Tabel berikut ini.

\begin{tabular}{llc}
\hline Produk & Waktu & Suhu $\left({ }^{\circ} \mathbf{C}\right)$ \\
\hline Es krim & 25 detik & 82,3 \\
& 30 menit & 71,2 \\
Telur & 3,5 menit & 60 \\
Jus buah & 15 menit & $60-70$ \\
& 1 menit & $80-85$ \\
wine & 1 menit & $82-85$ \\
acar pH 3,7 & 15 menit & 74 \\
cuka & 1 menit & $65,6-71,1$ \\
& 30 menit & 60 \\
Daging & 10 menit & 70 \\
kepiting & & \\
\hline
\end{tabular}

Pada beberapa produksi pangan fermentasi, bahan baku pembuatannya 
dipanaskan pada suhu tinggi untuk membunuh mikroorganisme patogen dan pembusuk, termasuk sel bakteri thermodurik. Contohnya pada pembuatan buttermilk dan yogurt, bahan bakunya dipanaskan pada suhu $90{ }^{\circ} \mathrm{C}$ selama 30-60 menit.

b. Pemanasan suhu tinggi

Pemanasan suhu tinggi, contohnya pada proses sterilisasi. Suhu yang digunakan dalam proses pemanasan tergantung dari karakteristik bahan dan juga karakteristik dari mikroorganisme yang akan dihilangkan. Target mikroba dari pemanasan suhu tinggi adalah mikroba yang resiten terhadap panas. Terdapat dua macam sterilisasi, yaitu sterilisasi total dan sterilisasi komersial. Sterilisasi komersial tidak absolut membunuh mikroba. Sterilisasi komersial bisa membunuh spora Clostridium botulinum Type A dan B akan tetapi spora dari Bacillus stearothermophilus, Bacillus coagulans, Clostridium Thermosaccharolyticum, dan Desulfotomaculum nigrificans biasanya masih hidup.

Dikarenakan ada spora yang masih hidup meskipun makanan dipanaskan dengan suhu tinggi. Maka penyimpanan bahan makanan 
harus

memperhatikan

suhu

penyimpanannya. Penyimpanan pada suhu kurang dari $30{ }^{\circ} \mathrm{C}$ dapat mencegah spora bergeminasi. Sedangkan jika makanan disimpan pada suhu lebih atau kurang sama dengan $40{ }^{\circ} \mathrm{C}$ spora mikroba thermofil dapat bergerminasi.

Sehingga

meskipun penyimpanan berikutnya pada suhu kurang dari $30{ }^{\circ} \mathrm{C}$, tidak dapat mencegah pertumbuhan spora sehingga makanan tersebut mengalami kerusakan.

Bahan pangan yang berasam tinggi atau mempunyai nilai $\mathrm{pH}$ rendah $(\mathrm{pH} \leq 4.6)$ seperti produk dari tomat, produk dari buah, dan makanan yang diasamkan membutuhkan suhu yang lebih rendah untuk proses pemanasannya. Dikarenakan, spora Clostridium botulinum tidak dapat tumbuh pada $\mathrm{pH}$ yang rendah. Pada bahan pangan dengan $\mathrm{pH}$ rendah, spora yang dapat bergerminasi adalah spora dari Bacillus coagulans, Lactobacillus, dan Leuconostoc spp., khamir, dan kapang. Spora tersebut relatif sensitif terhadap panas, sehingga pemanasan pada suhu $100{ }^{\circ} \mathrm{C}$ dalam kurun waktu tertentu dapat membunuh spora tersebut.

Sterilisasi komersial dapat dilakukan pada suhu yang tinggi dengan waktu yang 
singkat, atau yang biasa disebut UHT (UItra High Temperature). UHT dilakukan selama 23 detik pada suhu $150{ }^{\circ} \mathrm{C}$. Bahan pangan yang diolah secara UHT memiliki beberapa kelebihan, diantaranya adalah dapat disimpan pada suhu ruang $\left(\leq 30^{\circ} \mathrm{C}\right)$ dan masa simpan dari produk yaitu selama 3 bulan. Susu yang dipanaskan secara UHT tetap bisa mengalami kerusakan dalam jangka waktu tertentu diakibatkan ada beberapa enzim yang berada di bahan baku susu itu sendiri. Dimana enzim tersebut tahan terhadap panas. Ezim yang berada pada bahan baku susu itu adalah enzim proteinase dan lipase.

c. Pemanasan dengan microwave Pemanasan dengan microwave memanfaatkan adanya gelombang panas yang mengakibatkan pergerakan molekul air dalam bahan pangan. Suhu bahan pangan mengalami kenaikan dengan cepat sehingga dapat merusak mikroorganisme. Bahan pangan beku dapat dilakukan proses thawing menggunakan microwave. Waktu yang dibutuhkan tergantung dari ukuran produk tersebut. Pemanasan yang tidak merata dapat menyebabkan tumbuhnya mikroba patogen, dikarenakan ada bagian yang masih dingin yang disebut dengan cold spots. 
D. Preservasi Bahan Pangan dengan Suhu Rendah

Tujuan preservasi bahan pangan dengan suhu rendah yaitu untuk menekan pertumbuhan mikroba. Selain untuk menghambat pertumbuhan mikroba suhu rendah juga dapat menekan aktifitas enzimatik dari mikroba. Misalnya enzim lipase dan proteinase. Penyimpanan pada suhu rendah juga dapat membunuh $90 \%$ atau lebih populasi mikroba akan tetapi preservasi dengan suhu rendah tidak bisa mematikan spora yang ada pada bahan pangan.

Mekanisme kerja antimikroba dengan suhu rendah yaitu pada suhu rendah aktifitas mikroba juga menurun. Air dalam bahan pangan terdiri dari air bebas dan air terikat. Pada suhu $-2{ }^{\circ} \mathrm{C}$ air dalam bahan mulai membeku dan pada suhu $-20{ }^{\circ} \mathrm{C}$ semua air dalam bahan membeku. Pada suhu $-2{ }^{\circ} \mathrm{C}$ saat air dalam bahan mulai membeku, air dalam sel mikroba berdifusi keluar sehingga menyebabkan dehidrasi sel. Jika temperatur terus diturunkan hingga $-20{ }^{\circ} \mathrm{C}$ air dalam sel mikroba juga membeku. Hal ini menyebabkan denaturasi dan destabilisasi struktur dan fungsi makromolekul dari sel mikroba.

Efektivitas penanganan suhu rendah untuk mengontrol aktivitas mikroba dipengaruhi oleh tiga faktor yaitu jenis proses, kondisi bahan, dan jenis mikroorganisme. 
1. Jenis Proses

Pembekuan pada suhu $-2{ }^{\circ} \mathrm{C}$ untuk beberapa khamir dan jamur masih dapat tumbuh, tetapi fase pertumbuhan yaitu pada fase lag (adaptasi) dan fase eksponensial menjadi lebih lama. Hal ini juga terjadi pada bakteri Pseudomonas fluoroscens, pertumbuhan Pseudomonas fluoroscens selama 6,7 jam pada suhu $0,5^{\circ} \mathrm{C}$, tetapi menjadi 32,2 jam pada suhu $0{ }^{\circ} \mathrm{C}$.

Fluktuasi suhu makanan selama penyimpanan suhu rendah berakibat besar terhadap pertumbuhan, kerusakan dan kematian mikroorganisme. Kecepatan pendinginan juga sangat penting untuk mengontrol pertumbuhan mikroba patogen dan pembusuk. Meskipun bahan pangan yang disimpan pada suhu dingin dapat mencegah pertumbuhan mikroorganisme, akan tetapi masa simpan bahan pangan tersebut juga memiliki batas waktu.

2. Kondisi Bahan

Komposisi bahan pangan, $\mathrm{pH}$, kadar air, dan adanya mikroba penghambat dari bahan pangan dapat mempengaruhi kelangsungan hidup mikroba. Makanan padat (terutama tinggi protein, karbohidrat, dan lemak, tetapi rendah ion), $\mathrm{pH}$ netral atau diatasnya, kadar air tinggi dan tidak mengandung mikroba penghambat memudahkan 
pertumbuhan mikroorganisme pada suhu dingin. Daya simpan bahan pangan yang disimpan didalam lemari es dapat ditingkatkan dengan cara mengurangi $\mathrm{pH}$, kadar air, dan menambahkan mikroba penghambat dan sedapat mungkin diperhatikan jenis pengemas dan cara mengemas dalam proses penyimpanan.

3. Jenis mikroorganisme

Meskipun beberapa mikroba dapat hidup pada suhu $\quad-10{ }^{\circ} \mathrm{C}$ tetapi mikroba termofilik dan mesofil dapat rusak bahkan mati pada suhu rendah selama pembekuan. Preservasi bahan pangan dengan suhu rendah dapat menyebabkan sel vegetatif bakteri dapat rusak dan mati. Pada umumnya bakteri gram negatif lebih rentan daripada gram positif. Seperti Clostridium sp. dan Bacillus sp. Pada makanan yang disimpan beku spora dari mikroba masih bisa dipertahankan dan beberapa mikroba dapat mengkatalis reaksi enzimatik pada suhu $-20{ }^{\circ} \mathrm{C}$ dan dapat mengurangi kualitas bahan.

Metode yang digunakan pada preservasi bahan pangan dengan suhu rendah diantaranya adalah ice chilling, refrigeration, dan freezing.

1. ice chilling

Metode ini menggunakan es beku yang diletakkan diatas bahan. Suhu permukaan bahan yang bersentuhan dengan es berkisar antara $0-1{ }^{\circ} \mathrm{C}$. Bahan pangan yang bisa menggunakan metode ini 
diantaranya adalah ikan segar, makanan laut (seafood), daging, buah, salad sayuran, dan berbagai jenis makanan siap saji. Fluktuasi suhu dan kontaminasi silang antara bahan dengan wadah yang terbuka dapat terjadi, dan dapat menimbulkan foodborne disease.

\section{Refrigeration}

Pengaturan suhu rendah, kelembaban udara, jarak yang tepat antar produk harus diperhatikan pada saat kita penyimpanan bahan pangan di dalam lemari es. Bahan baku dan bahan pangan siap saji dapat disimpan pada lemari es, beberapa diantaranya dapat bertahan selama 60 hari atau lebih. Pada produk yang kurang bersih (kurang steril), mikroba pembusuk dan patogen masih dapat tumbuh dan berkembang biak selama penyimpanan sehingga mengurangi stabilitas dan keamanan pangan.

\section{Freezing}

Temperatur minimum pada pembekuan (lemari es) adalah $-20{ }^{\circ} \mathrm{C}$ dimana seluruh air mulai membeku. Proses pembekuan juga dapat dilakukan dengan menggunakan es kering $\left(-78^{\circ} \mathrm{C}\right)$ dan nitogen cair $\quad\left(-196^{\circ} \mathrm{C}\right)$. Selama pembekuan suhu bahan dipertahankan sekitar -20 sampai -30 C. Bahan baku seperti buah dan sayur, daging, ikan dan makanan siap saji dapat disimpan menggunakan metode ini. Pada makanan beku proses pencairan (thawing) 
diperlukan sebelum bahan tersebut diolah. Akan tetapi kesalahan dalam proses pencairan dan lamanya proses pencairan dapat memicu pertumbuhan bakteri patogen dan pembusuk.

\section{E. Preservasi Bahan Pangan dengan Penurunan Aw}

Bahan pangan mengandung dua macam air, yaitu air bebas dan air terikat. Air bebas atau biasa disebut dengan Aktivitas air (Aw) yaitu air yang mudah hilang apabila bahan pangan diuapkan atau dikeringkan. Aw inilah yang sering menjadi media tumbuh perkembangbiakan mikroba serta reaksi-reaksi kimia dalam bahan pangan. Nilai Aw dinyatakan dalam angka desimal dengan kisaran 0 - 1,0. Sedangkan air terikat yaitu air yang terikat erat dengan komponen bahan pangan.

Pada dasarnya bahan pangan yang belum diolah seperti susu, ikan, daging, dan telur mempunyai Aw 0,95. Sebagian besar mikroba yang bisa tumbuh pada kisaran Aw yang tinggi yaitu golongan bakteri. Untuk bahan pangan kering seperti tepung, biji-bijan kering, kacangkacangan kering, buah-buahan kering mempunyai nilai Aw 0,60 - 0,85. Pada bahan kering seperti ini mikroba yang sering tumbuh adalah dari golongan kapang. Hal ini menunjukkan bahwa pada setiap jenis mikroba mempunyai kisaran Aw yang berbeda-beda untuk pertumbuhannya. Jika dibuat dalam bentuk tabel akan terlihat seperti Tabel di bawah ini. 


\begin{tabular}{lll}
\hline No & Jenis mikroba & Aw \\
\hline 1 & Bakteri & $\geq 0,91$ \\
2 & Khamir & 0,88 \\
3 & Kapang & 0,80 \\
\hline
\end{tabular}

Beberapa bakteri tertentu ada yang dapat tumbuh pada Aw sampai 0,75. Dan untuk beberapa khamir ada yang tumbuh pada Aw sampai 0,60. Dibawah Aw minimal dari setiap kisaran Aw untuk tiap mikroba tidak dapat tumbuh dan berkembang biak. Pertumbuhan mikroba dapat dihambat secara total dengan menurunkan Aw bahan pangan dibawah 0,60. Oleh karena salah satu metode preservasi bahan pangan dalam rangka memperpanjang daya simpan dari produk pangan yaitu dengan cara menurunkan Aw dari bahan pangan tersebut.

Penurunan Aw bahan pangan dipengaruhi oleh beberapa faktor diantaranya adalah:

1. Jenis Proses

Bahan terlarut berbeda dalam kemampuannya untuk menurunkan Aw pada produk pangan. Pada air murni dengan suhu $25{ }^{\circ} \mathrm{C}$ untuk menurunkan Aw menjadi 0.99 dibutuhkan konsentrasi $\mathrm{NaCl}$, sukrosa, glukosa, dan gula invert berturut-turut 1.74, 15.45, 8.9, dan 4.11 g. Sedangkan untuk menurunkan Aw air murni menjadi 0.92 dibutuhkan konsentrasi larutan berturut-turut 11.9, 54.34, 43.72, dan $32.87 \mathrm{~g}$. 
2. Karakteristik Bahan Pangan

Nilai Aw minimal untuk pertumbuhan mikroorganisme bervariasi tergantung karakteristik bahan pangan dan kondisi lingkungan selama penyimpanan.

3. Jenis Mikroorganisme

Mikroorganisme sangat berbeda dalam kebutuhan Aw minimal mereka untuk pertumbuhannya, membentuk spora, dan bergerminasi. Pada umumnya kapang dan khamir dapat tumbuh pada Aw yang lebih rendah daripada bakteri patogen dan pembusuk. Bakteri gram negatif membutuhkan Aw yang sedikit lebih tinggi daripada bakteri gram positif. Secara lebih detail untuk kebutuhan Aw minimal pada mikroorganisme dapat dilihat pada Tabel berikut ini.

Tabel Aw minimum pertumbuhan mikroba pada suhu optimum pertumbuhannya

\begin{tabular}{ll}
\hline \multicolumn{1}{c}{ Mikroorganisme } & Aw \\
\hline Bakteri & \\
Bacillus cereus & 0.95 \\
Bacillus stearothermophilus & 0.93 \\
Clostridium botulinum Type A & 0.95 \\
Clostridium botulinum Type B & 0.94 \\
Clostridium botulinum Type E & 0.97 \\
Clostridium perfringens & 0.95 \\
Escherichia coli & 0.95
\end{tabular}


Salmonella spp.

0.95

Vibrio parahaemolyticus $\quad 0.94$

Staphylococcus aureus $\quad 0.86$

Pseudomonas fluorescens $\quad 0.97$

Lactobacillus viridescens $\quad 0.94$

Khamir

Saccharomyces cerevisiae $\quad 0.90$

Saccharomyces rouxii $\quad 0.62$

Debaryomyces hansenii $\quad 0.83$

Kapang

Rhizopus nigricans $\quad 0.93$

Penicillium chrysogenum $\quad 0.79$

Penicillium patulum $\quad 0.81$

Aspergillus flavus $\quad 0.78$

Aspergillus niger $\quad 0.77$

Alternaria citri $\quad 0.84$

Metode penurunan Aw yang dapat dilakukan untuk mencegah pertumbuhan mikroorganisme cukup beragam, diantaranya adalah:

1. Pengeringan alami

Metode ini merupakan metode yang paling murah karena pengurangan Aw dari bahan pangan dihilangkan dengan menggunakan panas matahari. Metode ini biasanya digunakan untuk bahan pangan seperti biji-bijian kering, buah-buahan kering seperti kismis, sayuran, ikan, daging, susu. 


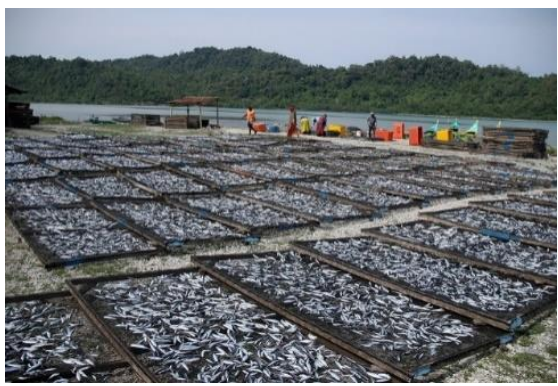

Proses penjemuran ikan asin

Meskipun metode ini murah tetapi metode ini juga mempunyai beberapa kekurangan. Kekurangan yang pertama yaitu proses pengeringannya lambat karena tergantung kondisi cuaca pada saat itu. Selain itu pengeringan dengan cara dijemur ini mempunyai resiko untuk ditumbuhi oleh bakteri pembusuk dan patogen, serta khamir ataupun jamur.

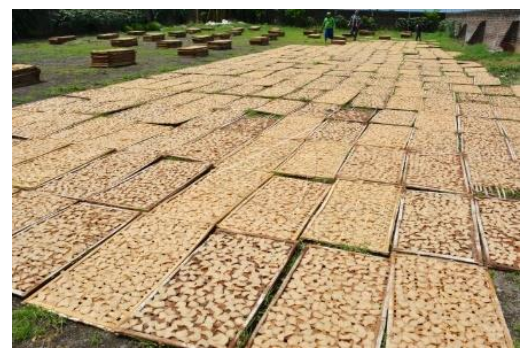

Proses penjemuran krupuk 
2. Pengeringan Mekanik

Pengeringan mekanik adalah proses yang dikendalikan. Proses pengeringan metode ini berlangsung dalam waktu beberapa detik sampai beberapa jam tergantung jenis metode yang digunakan dan bahan yang dikeringkan. Bahan yang biasanya dikeringkan menggunakan metode pengeringan mekanik adalah sayuran, buah-buahan, jus buah, susu, kopi, teh, dan dendeng daging. Beberapa metode yang digunakan dalam pengeringan mekanik diantaranya adalah:

a. Tunnel drying

Penghilangan air pada bahan pangan dengan metode ini dilakukan dengan cara melewatkan bahan pangan tersebut kedalam terowongan yang dialiri oleh udara panas.

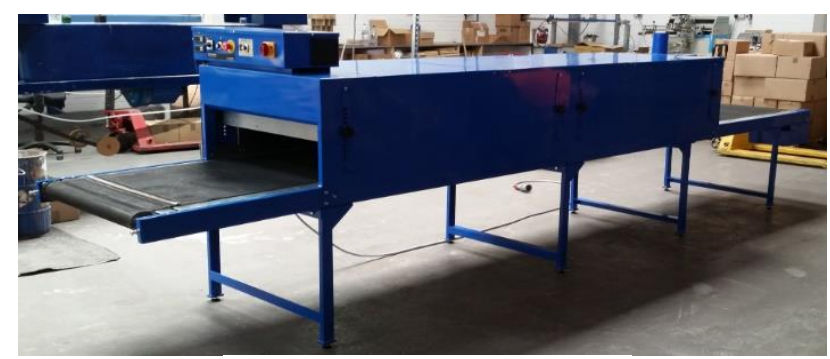

Tunnel dryer

b. Roller drying

Pengeringan metode ini dilakukan dengan cara, cairan yang dikeringkan diubah menjadi lapisan 
tipis pada permukaan roller drum yang dipanaskan dari dalam.

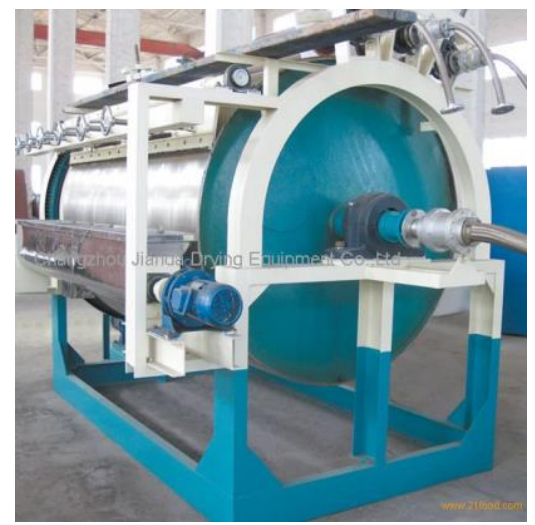

Roller drum

c. Spray Drying

Metode ini dilakukan dengan cara menyemprotkan cairan sehingga membentuk tetesan kecil. Kemudian tetesan tersebut bersentuhan dengan udara panas sehingga tetesan tersebut berubah menjadi kering.

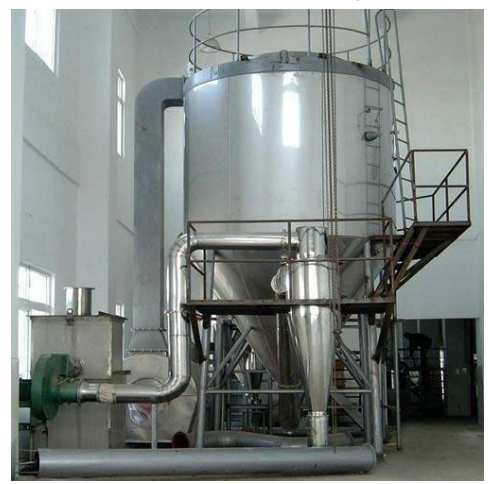

Spray dryer 
3. Pengeringan beku (Freeze Drying)

Kualitas penerimaan produk yang dikeringkan menggunakan metode pengeringan beku adalah yang paling sedikit jika dibandingkan dengan pengeringan alami dan pengeringan mekanik. Namun, pengeringan beku adalah metode yang membutuhkan biaya mahal untuk prosesnya. Metode pengeringan beku dapat diaplikasikan untuk bahan pangan yang berbentuk padat maupun cair.

Proses awal dari metode ini adalah proses pembekuan makanan, kemudian dengan cepat makanan tersebut mencapai suhu rendah. Kemudian makanan tersebut dibuat dalam kondisi vakum yang tinggi. Molekul air dihilangkan dari bahan pangan oleh sublimasi yaitu dari keadaan padat berubah menjadi uap tanpa mempengaruhi bentuk atupun ukurannya. Metode ini banyak digunakan untuk menghasilkan produk kering beku dari sayuran, buah-buahan, jus buah, kopi, teh, dan produk daging dan ikan, serta beberapa produk khusus lainnya.

4. Pengeringan busa (Foam Drying)

Pengeringan busa dilakukan dengan cara mengeringkan bahan pangan dengan cara menjadikan bahan pangan tersebut berbentuk busa. Bentuk busa disini bertujuan untuk meningkatkan luas permukaan dari bahan pangan yang akan dikeringkan. Busa dikeringkan oleh udara hangat. 
Produk-produk cair seperti putih telur, pure buah, dan pasta tomat dikeringkan dengan cara ini. Metode ini efek untuk mematikan sel mikroba dan spora cukup kecil. Sehingga perlu dilakukan metode preservasi lain sebelum dikeringkan seperti penurunan $\mathrm{pH}$ dan pengurangan aktivitas air.

5. Pengasapan

Metode pengasapan banyak diaplikasikan untuk produk daging dan ikan. Proses pengasapan ini akan menghilangkan air pada produk pangan sehingga aktivitas air pada bahan menurun. Contoh produk yang memanfaat metode ini yaitu, pada pembuatan sosis yang kering maupun yang semi kering serta ikan asap. Metode ini bisa membunuh mikroba yang ada dalam bahan pangan akibat panas dari asap dan juga senyawa antimikroba yang berada pada asap itu sendiri.

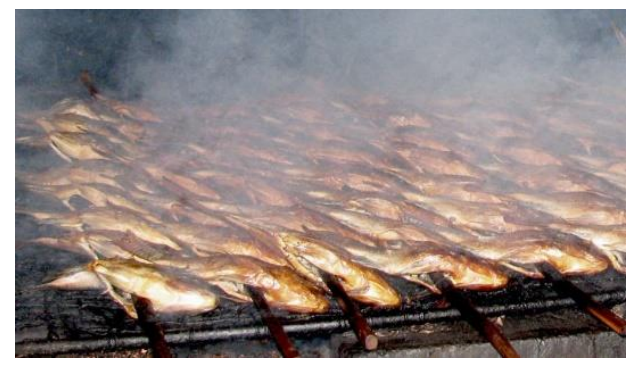

Proses pengasapan ikan 
6. Intermediate Moisture Foods (IMF)

Bahan pangan yang melalui proses IMF memiliki aktivitas air dengan kelembapan sampai $40 \%$. Bahan pangan tersebut dapat dikonsumsi tanpa melalui proses pengeringan akan tetapi mempunyai daya simpan yang cukup lama meskipun tidak disimpan pada suhu dingin. Dan hal ini diakui aman dari kontaminan mikrobiologis. Aktivitas air yang rendah dan kelembapan yang relatif tinggi tersebut diperoleh dengan cara menambahkan zat yang dapat mengikat air dan hidrofilik. Dikarenakan bahan pangan tersebut mengandung aktivitas air yang rendah maka bakteri tidak bisa berkembang.

K. Preservasi Bahan Pangan dengan Penurunan $\mathrm{pH}$ dan Asam Organik

Bahan makanan pada rentang $\mathrm{pH}$ tertentu, mikroorganisme masih bisa tumbuh pada bahan makanan tersebut. Akan tetapi jika $\mathrm{pH}$ makanan dibuat lebih rendah maka mikroorganisme bisa mati. Asam organik banyak digunakan sebagai bahan tambahan makanan. Asam organik tersebut selain berfungsi sebagai pengawet makanan juga berfungsi untuk memperbaiki kualitas bahan makanan. Asam organik bisa ada pada makanan dengan tiga cara.

1. Secara alami sudah ada dalam makanan. Misalnya asam sitrat pada buah jeruk, asam benzoat dalam buah cranberry, dsb. 
2. Melalui proses fermentasi. Seperti asam asetat, asam laktat, dan asam propionat yang ditemukan pada makanan fermentasi.

3. Penambahan asam organik. Banyak jenis asam yang biasanya ditambahkan pada makanan untuk menurunkan $\mathrm{pH}$. Penambahan asam berfungsi sebagai pengawet. Asam tersebut diantaranya adalah asam asetat, asam propionat, asam laktat, asam sitrat, asam sorbet, asam benzoat, dan paraben.

Efektivitas penurunan Aw dipengaruhi oleh beberapa factor, diantaranya adalah sifat asam, sifat bahan, dan sifat mikroorganisme.

1. Sifat Asam

Secara umum dalam kondisi yg sama, efektivitas antimikroba dari empat asam berturut-turut yaitu asam asetat > asam propionat $>$ asam laktat $>$ asam sitrat. Pada $\mathrm{pH}$ yang lebih rendah dan konsentrasi yang lebih tinggi, asam lebih bersifat antimikroba. Beberapa asam menunjukkan efek sinergis bila digunakan dalam kombinasi yang tepat dengan asam lain. Seperti contohnya asam asetat dengan asam laktat, asam propionat denngan asam sorbat, asam benzoat dengan nisin, asam propionat, asam asetat, atau asam laktat dengan nisin atau pediosin $\mathrm{AcH}$, asam propionat atau benzoat dengan $\mathrm{CO} 2$. 
2. Sifat Bahan

$\mathrm{pH}$ normal makanan sangat bervariasi, dari kisaran yang sangat asam seperti pada jus jeruk (pH 3.0) hingga kisaran basa seperti pada albumin telur ( $\mathrm{pH}$ 9.0). $\mathrm{pH}$ awal sangat mempengaruhi efek antimikroba. Asam lebih menghambat dalam makanan dengan $\mathrm{pH}$ lebih rendah daripada di makanan dengan $\mathrm{pH}$ lebih tinggi.

3. Sifat Mikroorganisme

Mikroorganisme yang ada dalam makanan sangat bervariasi pada batas bawah $\mathrm{pH}$ yang memungkinkan mikroorganisme dapat tumbuh. Secara umum bakteri gram negatif lebih sensitif terhadap $\mathrm{pH}$ rendah daripada bakteri gram positif. Khamir dan kapang adalah jenis mikroorganisme yang paling tidak sensitif terhadap $\mathrm{pH}$ rendah. Sifat antimikroba dari asam organik dapat meningkat dengan adanya panas, Aw rendah, adanya beberapa pengawet lain, dan suhu penyimpanan yang rendah. Mikroorganisme berbeda dalam kepekaannya terhadap asam organik yang berbeda. Khamir dan kapang sangat sensitif terhadap asam propionat dan sorbat, bakteri lebih sensitif terhadap asam asetat. 
Tabel $\mathrm{pH}$ minimum dimana mikroorganisme dapat tumbuh

\section{Mikroorganisme}

\begin{tabular}{ll}
\hline \multicolumn{1}{c}{ Mikroorganisme } & \multicolumn{1}{c}{ pH minimum } \\
& untuk tumbuh \\
\hline Bakteri gram negatif & \\
Escherichia coli & 4.4. \\
Pseudomonas spp. & 5.6 \\
Salmonella & 4.5 \\
Vibrio spp. & 4.8 \\
Serratia spp. & 4.4 \\
Bakteri gram positif & \\
Bacillus cereus & 4.9 \\
Bacillus & 5.2 \\
stearothermophilus & \\
Clostridium botulinum & 4.6 \\
Clostridium perfringens & 5.0 \\
Enterococcus faecalis & 4.4 \\
Lactobacillus spp. & 3.8 \\
Staphylococcus aureus & 4.0 \\
Listeria monocytogenes & 4.6 \\
Khamir & \\
Candida spp & $1.5-2.3$ \\
Saccharomyces spp. & $2.1-2.4$ \\
Hansenula spp. & 2.1 \\
Rhodotorula spp. & 1.5 \\
Kapang & \\
Aspergillus spp. & 1.6 \\
Penicillium spp. & $1.6-1.9$ \\
Fusarium spp. & 1.8 \\
\hline & \\
\hline
\end{tabular}


Beberapa jenis asam organik yang biasanya digunakan diantaranya adalah.

1. Asam asetat

Asam asetat biasanya digunakan sebagai cuka dengan konsentrasi $5-10 \%$ atau sebagai garam natrium dan kalsium pada kadar $25 \%$ atau lebih tinggi dalam pembuatan acar, saus salad, dan saus. Asam asetat lebih efektif melawan bakteri daripada khamir dan kapang. Bakteri yang tumbuh lebih baik pada $\mathrm{pH}$ diatas 6.0 lebih terhambat. Selain digunakan dalam pembuatan makanan, asam asetat juga bisa digunakan dalam pencucian karkas untuk mengurangi jumlah bakteri dengan konsentrasi asam asetat $1-2 \%$.

2. Asam propionat

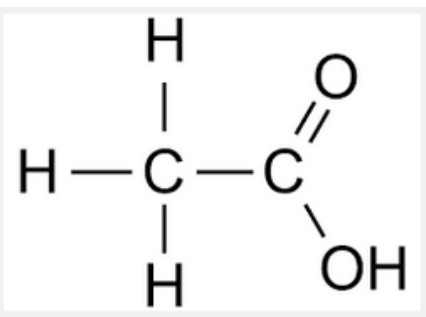

Asam propionat Asam asetat agai garam kalsium dan natrium pada konsentrasi 1000 - 2000 ppm $(0.1-0.2 \%)$ dalam pembuatan roti, produk roti, keju, selai, jeli, dan bubur tomat. Asam propionat efektif melawan kapang dan bakteri tetapi hampir tidak efektif melawan khamir. Konsentrasi 
penghambatan asam tak terdisosiasi adalah $0.05 \%$ terhadap kapang dan bakteri.

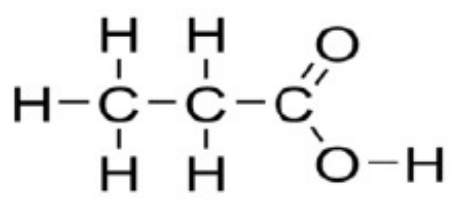

Asam propionat

3. Asam laktat

Asam laktat biasanya digunakan pada konsentrasi sampai $2 \%$ dalam minuman berkarbonasi, saus salad, acar sayuran, produk daging olahan dengan panas rendah, dan saus. Asam laktat kurang efektif dibandingkan asam asetat, propionat, benzoat, atau sorbat, tetatpi lebih efektif daripada asam sitrat. Asam laktat efektif melawan bakteri tetapi tidak cukup efektif melawan kapang dan khamir.

4. Asam s

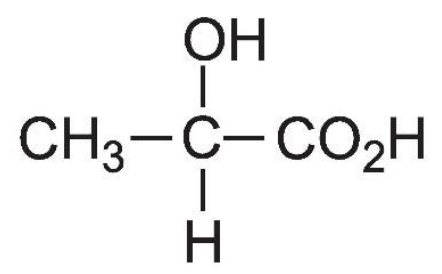

Asi Asam laktat (Asam 2-Hidroksi Propanoat) - h) dalam minuman non-alkonol, selaı dan jelı, proquk kue, keju, sayuran kaleng, dan saus. Asam sitrat kurang 
efektif dibandingkan asam laktat melawan bakteri serta khamir dan kapang.

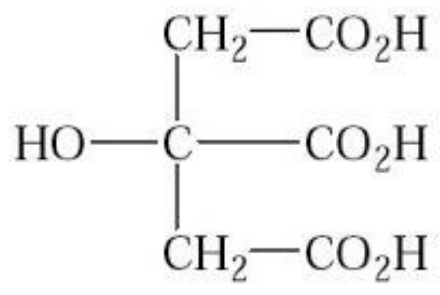

\section{Asam sitrat}

5. Asam sorbat

Asam sorbat digunakan dalam minuman nonalkohol, beberapa minuman beralkohol, olahan buah dan sayur, desserts berbahan susu, permen-permen an, mayones, saus salad, olesan, dan mustard. Konsentrasi yang digunakan anatara $500-2000$ ppm (0.05 - $0.2 \%)$. Asam sorbat lebih efektif melawan kapang dan khamir daripada melawan bakteri. Bakteri katalase negatif (misalnya, bakteri asam laktat) lebih tahan daripada bakteri katalase positif (misalnya $S$. aureus dan Bacillus spp.). selain itu, bakteri aerob lebih sensitif terhadap asam sorbat daripada bakteri anaerob.

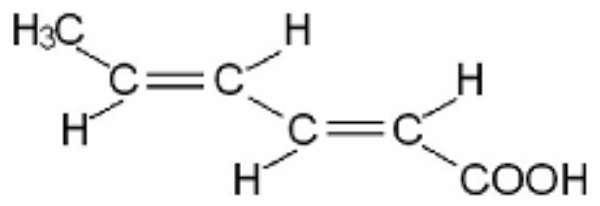


6. Asam benzoat

Asam benzoat digunakan sebagai asam atau garam sodium dengan konsentrasi 500 - 2000 ppm (0.05 0.2 ) dalam banyak produk dengan $\mathrm{pH}$ rendah. Seperti minuman non alkohol dan alkohol, acar, permenpermean, mayones, saus salad, mustard, dan keju cottage. Asam benzoat lebih efektif melawan khamir dan kapang daripada bakteri.

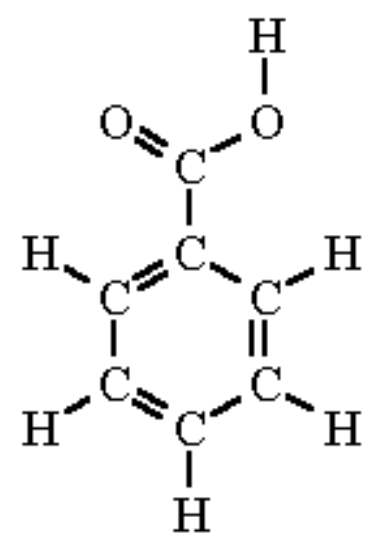

Asam benzoat

7. Parabens

Parabens digunakan sebagai metil, etil, butil, atau propil paraben. Parabens digunakan pada $100-1000$ ppm $(0.01-0.1 \%)$ dalam minuman non-alkool dan beralkohol, isian dari buah, selai dan jeli, acar, permen, saus salad, olesan, dan mustard. 


\section{Xenoestrogens \\ The Paraben Family \\ (para-hydroxy alkylbenzoates)}

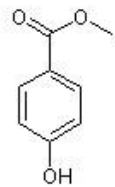

Methylparaben

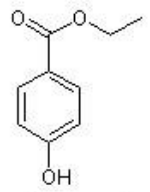

Ethylparaben

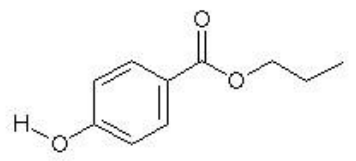

Propylparaben<smiles>CCCCOC(=O)c1ccc(O)cc1</smiles><smiles>CC12CCC3c4ccc(O)cc4CCC3C1CCC2O</smiles>

\section{Estrogen}

for comparison

L. Preservasi Bahan Pangan dengan Metode Kombinasi (Hurdle Concept)

Banyak metode preservasi yang bisa dilakukan diantaranya adalah penggunaan panas, $\mathrm{pH}$ rendah, Aw rendah, suhu rendah, dan lain - lain. Beberapa metode ini akan menyebabkan kerusakan sel dan spora mikroorgaisme. Sel dan spora yang mengalami kerusakan 
oleh satu metode tersebut menjadi sensitif terhadap metode lainnya sehingga sel dan spora menjadi mati. Kerusakan subletal pada sel mikroba dan spora serta peningkatan kerentanan sel dan spora yang terluka terhadap satu atau lebih metode pengawetan memainkan peran penting dalam mengendalikan mikroorganisme dengan kombinasi berbagai faktor.

Perlu dipelajari efek menguntungkan dari menggabungkan metode preservasi yang berbeda untuk menentukan efisiensi antimikroba terhadap mikroorganisme target dalam pangan. Metode kombinasi (hurdle concept) adalah Jika dua atau lebih metode preservasi digunakan bersama maka akan lebih efektif, bahkan pada tingkat perlakuan yang jauh lebih rendah. Beberapa metode kombinasi yang bisa dilakukan adalah sebagai berikut.

1. Pemanasan suhu rendah

Suhu rendah tidak membunuh banyak spora bakteri patogen dan pembusuk. Spora tersebut dapat melakukan germinasi dan pertumbuhan. Namun, jika pH diturunkan menjadi 4.5 atau ditambahkan $\mathrm{NO}_{2}$ atau $\mathrm{NaCl}$ maka spora tidak dapat melakukan germinasi karena mengalami heat-shock.

2. Penyimpanan suhu rendah

Clostridium botulinum tumbuh pada suhu 35 ${ }^{\circ} \mathrm{C}$ pada Aw 0.95. Namun jika suhu penyimpanan diturunkan menjadi $20^{\circ} \mathrm{C}$, Clostridium botulinum 
tidak akan tumbuh kecuali Aw ditingkatkan menjadi 0.97. begitu pula dengan Lis. monocytogenes tumbuh pada suhu $25{ }^{\circ} \mathrm{C}$ dalam larutan yang mengandung $\mathrm{NaCl}$ dengan konsentrasi $6.5 \%$ dalam tiga hari, tetapi pertumbuhan tidak bisa dilakukan jika suhu diturunkan menjadi $14{ }^{\circ} \mathrm{C}$.

3. $\mathrm{pH}$ rendah

Clostridium botulinum tumbuh pada $\mathrm{pH} 7.0$, $37^{\circ} \mathrm{C}$, dan pada Aw 0.94. Ketika pH diturunkan menjadi 5.3 Clostridium botulinum tidak dapat tumbuh meskipun Aw 0.99. Strain Salmonella tumbuh pada $\mathrm{pH} 5.8$ pada Aw 0.97, tetapi bila $\mathrm{pH}$ diturunkan menjadi 5.0, diperlukan Aw 0.99 untuk Salmonella bisa tumbuh. Clostridium botulinum menghasilkan toksin selama inkubasi pada suhu $16{ }^{\circ} \mathrm{C}$ dalam waktu 28 hari pada $\mathrm{pH} 5.5$, tetapi pada $\mathrm{pH} 5.2$ dalam kondisi yang sama tidak ada toksin yang dihasilkan. Dalam menggunakan asam untuk menurunkan $\mathrm{pH}$, penting diketahui bahwa asam organic seperti asam asetat, propionate, dan laktat lebih efektif daripada $\mathrm{HCl}$ dan asam fosfat. Selain itu, asam setat atau propionate lebih efektif daripada asam laktat

4. Aw rendah

S. aureus dapat tumbuh pada Aw 0.86 dan $\mathrm{pH}$ tinggi. Namun, S. aureus tidak dapat tumbuh 
dengan adanya $\mathrm{NaCl}$ pada $\mathrm{pH} 4.6$ bahkan pada $\mathrm{Aw}$ 0.93. Dibutuhkan $\mathrm{pH}$ yang lebih tinggi untuk mendukung pertumbuhan $S$. aureus. Hal yang sama juga terjadi pada $S$. aureus tumbuh pada suhu $12{ }^{\circ} \mathrm{C}, \mathrm{pH} 7.0$, dan Aw 0.93. Namun, jika Aw diturunkan menjadi $0.90 \mathrm{~S}$. aureus tidak dapat tumbuh meskipun dalam kondisi yang sama. Penting juga untuk diketahui bahwa pada Aw rendah, beberapa mikroorganisme mempunyai resistensi terhadap efek mematikan dari panas.

5. Modified Atmosphere

Dalam makanan kemasan vakum yang menggunakan $\mathrm{N}_{2}$ atau $\mathrm{CO}_{2}$, pertumbuhan mikroba aerob dapat dicegah dan mikroba fakultatif anaerob dapat dikurangi. Akan tetapi dikhawatirkan kemasan vakum dapat secara selektif menjadi tempat pertumbuhan bakteri pembusuk anaerobik dan patogen. Oleh karena itu, perlu dilakukan kombinasi dengan metode lain seperti penurunan $\mathrm{pH}$, penurunan $\mathrm{Aw}$, penggunaan pengawet, dll untuk mengontrol pertumbuhan mikroorganisme.

6. Bahan Pengawet

Beberapa bahan pengawet seperti $\mathrm{NaCl}$ dan BHA bekerja secara sinergis untuk meingkatkan efek antimikroba pada sorbet. Asam organik juga efektif pada $\mathrm{pH}$ rendah. Beberapa pengawet 
mungkin tidak efektif pada $\mathrm{pH}$ yang lebih tinggi dan beberapa mungkin kehilangan potensi selama penyimpanan. Bakteriosin dapat dihancurkan oleh enzim proteolitik yang ada dalam makanan (makanan mentah). Efek bakteriosidal dari bakteriosin dapat ditingkatkan bila digunakan dengan asam, SDS, dan EDTA.

\section{Cleaning dan Sanitasi}

Jaringan internal tumbuhan dan hewan yang digunakan sebagai makanan pada dasarnya steril. Namun, banyak jenis mikroorganisme mampu menyebabkan pembusukan makanan dan penyakit bawaan makanan masuk dari sumber yang berbeda. Tidak mungkin untuk mencegah akses mikroorganisme dalam makanan dari sumber ini.

Namun, kita dapat mengontrol akses mikroba tersebut pada makanan untuk meminimalkan pembusukan mikroba dan bahaya kesehatan. Hal ini menunjukkan perlunya metode yang lebih efektif untuk mengontrol akses mikroba untuk makanan melalui sanitasi yang efisien.

Tujuan dari dilakukan cleaning dan sanitasi adalah:

- Sanitasi digunakan untuk meminimalkan akses mikroorganisme dalam makanan dari berbagai sumber di semua tahapan penanganan. Karena sumber mikroba dan tingkat penanganan bervariasi. 
- Sanitasi yang baik membantu mengurangi jumlah mikroba ke tingkat yang diinginkan dalam makanan yang diproses lebih lanjut.

- Sanitasi yang baik membantu menghasilkan makanan yang ketika benar saat ditangani dan disimpan, akan memiliki umur produk yang panjang. Akhirnya, sanitasi yang baik membantu mengurangi timbulnya penyakit bawaan makanan.

Beberapa faktor yang perlu dipertimbangkan diantaranya adalah:

a. Desain pabrik

Pada tahap awal merancang tempat dari pabrik pengolahan makanan, program sanitasi yang efisien harus diintegrasi untuk perlindungan maksimal terhadap kontaminasi mikroba pada makanan. Ini mencakup bagian luar dan bagian dalam dari sebuah pabrik.

Beberapa unsur untuk pertimbangan adalah spesifikasi lantai pabrik, bahan kontruksi yang telah ditetapkan, cahaya yang memadai, ventilasi udara, arah aliran udara, pemisahan area untuk proses pengolahan produk mentah dan produk akhir, ruang yang cukup untuk pengoperasian dan bergerak, pipa saluran air, pasokan air, sistem pembuangan limbah, fasilitas pengolahan sampah, drainase, kondisi tanah, dan lingkungan sekitar.

b. Kualitas air, es, air garam, curing solution 
Kualitas mikrobiologi air ini, terutama jika makanan adalah tipe siap saji, tidak hanya terbebas dari patogen tetapi juga harus hanya mengandung bakteri pembusuk dalam jumlah yang rendah seperti Pseudomonas $s p$.

Es digunakan untuk chilling unpackaged sehingga makanan tidak terkontaminasi dengan bakteri patogen dan bakteri pembusuk. Demikian juga, air panas digunakan pada defeather chicken bisa menjadi sumber bakteri termodurik.

Air garam dan curing solution digunakan pada produk seperti ham, bacon, turkey-ham dan cured beef brisket dapat menjadi sumber kontaminasi mikroba. Untuk mengurangi ini, air garam dan curing solution harus dibuat dalam keadaan segar dan digunakan setiap hari.

c. Kualitas udara

Beberapa operasi pengolahan makanan seperti spray drying memerlukan udara dalam jumlah banyak untuk kontak langsung dengan makanan. Meskipun udara panas, tetapi tidak membunuh mikroorganisme yang berasal dari debu yang terbawa oleh udara. Pemasangan air inlets untuk memperoleh udara panas dengan jumlah debu yang sedikit dan filtrasi dari udara sangat penting untuk mengurangi kontaminasi mikroba pada sumber ini. 


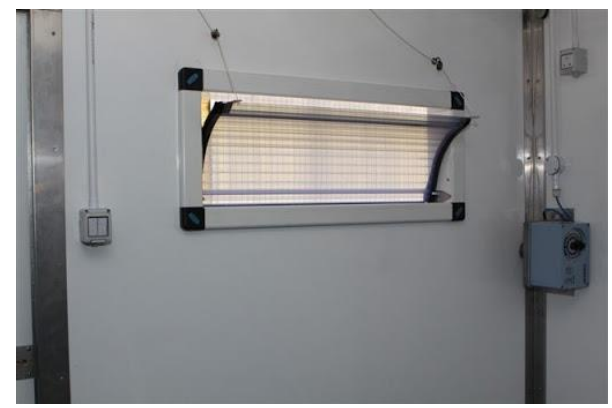

air inlets

d. Pelatihan personel

Sebuah pabrik pengolahan harus mempunyai program aktif untuk memberi pengarahan personil pabrik pentingnya sanitasi dan kebersihan personil untuk menjamin produk aman dan stabil.

Sebuah program itu tidak hanya memberi pengarahan bagaimana mencapai sanitasi yang baik dan kebersihan personal, tetapi juga memantau pelaksanaan dari program tersebut. Seseorang dengan penyakit dan infeksi harus dijauhkan dari penanganan produk.

e. Peralatan

Hal yang harus dipertimbangkan selama desain dari peralatan pengolahan makanan adalah melindungi makanan dari kontaminasi mikroba. Hal ini dapat dicapai jika peralatan tidak mengandung titik mati dimana mikroorganisme bersarang dan tumbuh. Alat yang dipakai harus mudah dibersihkan atau dibongkar. Beberapa peralatan seperti alat 
penggiling daging, choppers, atau pemotong dan tipe-tipe lain dari conveyor system, mungkin tidak dibersihkan secara efektif oleh karena itu menjadi sumber kontaminasi terbesar dari produk.

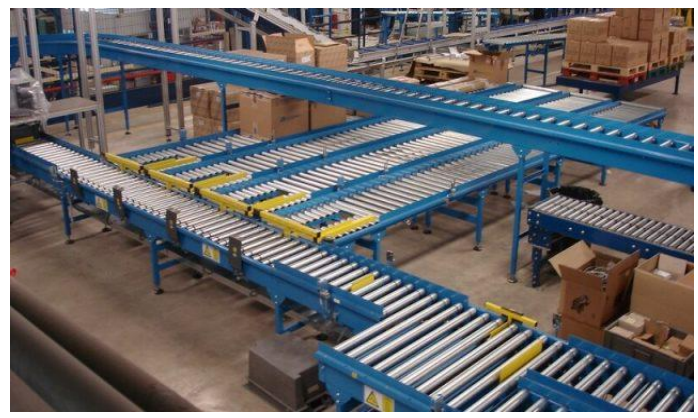

Conveyor system

f. Pembersihan fasilitas pengolahan

Pembersihan digunakan untuk menghilangkan tanah dan kotoran yang terlihat dan tidak terlihat dari sekeliling tempat pengolahan makanan dan peralatan. Untuk meningkatkan efesiensi dari pembersihan maka digunakan bahan kimia atau deterjen. Deterjen harus non korosif, aman, mudah dibasuh, dan sesuai yang diperlukan. Frekuensi pembersihan tergantung pada produk yang diproses. 


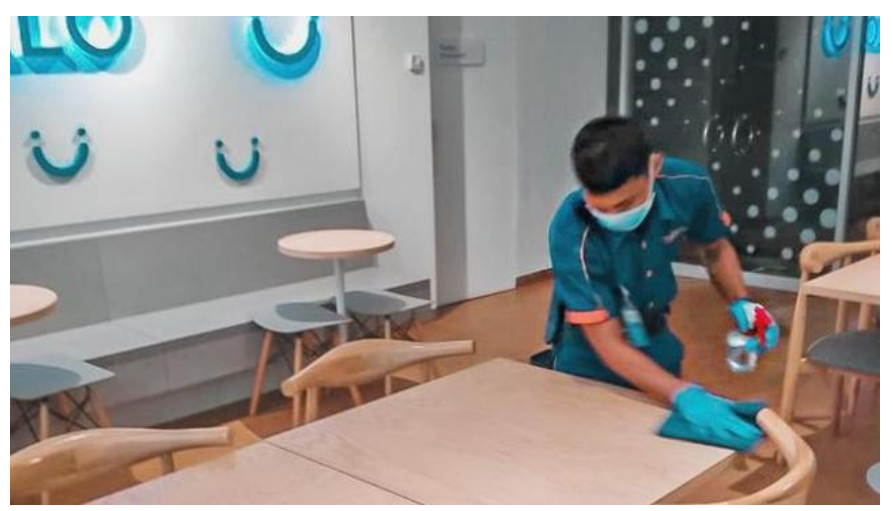

Sanitasi ruang produksi

g. Sanitasi peralatan pengolahan makanan

Pembersihan dapat menghilangkan beberapa mikroorganisme yang terdapat pada tanah yang kontak dengan permukaan makanan, tetapi tidak dapat memastikan menghancurkan seluruh mikroorganisme patogen. Beberapa metode fisik dan kimia digunakan untuk sanitasi peralatan pengolahan makanan. Metode fisik dilakukan dengan menggunakan air panas, uap, udara panas, dan radiasi UV. Sedangkan untuk metode kimia bisa menggunakan klorin, iodophores, senyawa kuarter ammonium, dan $\mathrm{H}_{2} \mathrm{O}_{2}$. 


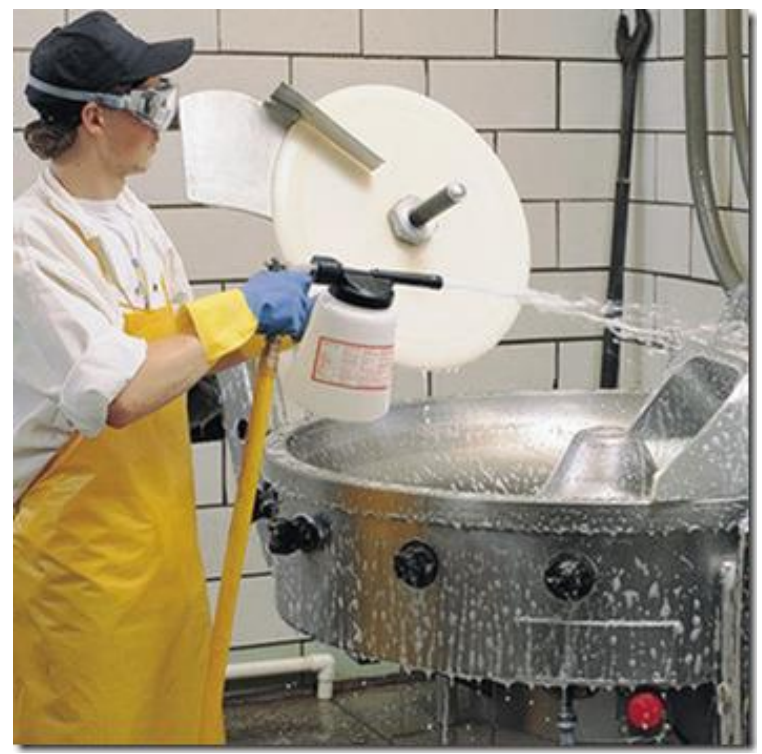

Sanitasi pelatan

h. Standar mikroba, spesifikasi, dan pedoman

Sebuah standar mikroba menentukan tingkat mikroba maksimum yang dapat diterima dalam suatu makanan. Contohnya adalah jumlah maksimum mikroba (SPC) untuk susu mentah adalah $100.000 / \mathrm{ml}$, susu yang dipasteurisasi SPC $20.000 / \mathrm{ml}$ dan koliform $\leq 10 / \mathrm{ml}$.

Sebuah spesifikasi menunjukkan maksimum jumlah mikroba yang diizinkan untuk penerimaan makanan atau makanan bahan. Misalnya untuk telur utuh memiliki spesifikasi sebagai berikut: plate count 
aerobik (APC) 25.000/g; coliform, 10/g; dan Salmonella harus negatif dalam $25 \mathrm{~g}$.

Pedoman mikrobiologi umumnya ditetapkan baik oleh peraturan lembaga atau pengolah makanan untuk membantu menghasilkan produk berkualitas.

N. Kesimpulan

- Upaya untuk mengawetkan bahan pangan dengan mempertahankan sifat fisik dan kimianya disebut dengan pengawetan makanan atau preservasi bahan pangan.

- Tujuan kita melakukan preservasi bahan pangan diantaranya adalah memperpanjang umur simpan dari produk, menghambat ataupun membunuh mikroba penyebab kerusakan bahan pangan, menghilangkan mikroba, dan mencegah kerusakan bahan pangan.

- Preservasi bahan pangan harus diperhatikan jenis bahan makanan yang diawetkan, keadaan bahan makanan, cara pengawetan, dan tujuan pengawetan itu sendiri.

- Metode preservasi yang bisa digunakan untuk mengawetkan bahan pangan diantaranya adalah dengan penggunaan suhu tingi, suhu rendah, penurunan $\mathrm{Aw}$, penurunan $\mathrm{pH}$, metode kombinasi (hurdle concept), serta cleaning dan sanitasi. 
O. Latihan Soal

1. Mengapa preservasi bahan pangan perlu dilakukan?

2. Ada banyak cara untuk preservasi bahan pangan, jika saudara mempunyai bahan pangan berupa susu apa yang saudara lakukan untuk memperpanjang daya simpan dari susu tersebut?

3. Ikan adalah bahan pangan yang mudah mengalami kerusakan karena kandungan air dan gizi yang tinggi. Salah satu cara untuk memperpanjang daya simpan dari ikan adalah dengan mengurangi aktivitas air (Aw). Apa saja cara yang bisa dilakukan untuk mengurangi aktivitas air (Aw) dari ikan tersebut?

4. Mengapa bahan pangan dengan $\mathrm{pH}$ yang rendah dapat memperpanjang daya simpan dari bahan pangan tersebut?

5. Coba beri contoh produk pangan yang ada disekitar anda, yang menerapkan konsep kombinasi (hurdle concept). Jelaskan juga masingmasing cara preservasi yang digunakan dalam konsep kombinasi tersebut! 


\section{Daftar Pustaka}

Adams, M. R. and Maurice O. M. 2008. Food Microbiology: Third Edition. RSC Publishing: UK

Cano, R.J. dan Colom, J.S. 1986. Microbiology. St. Paul, MN:

West Publishing Company

Frazier, W.C. dan Westhoff, D.C. 1979. Food Microbiology.

New Delhi, India: Tata McGraw Hill Company, Ltd.

Jay, J.M., Martin J.L., and David A.G. 2005. Modern Food Microbiology: Seventh Edition. Springer: United States of America

Lim, D. 1990. Microbiology. McGrow-Hill Book, New York

Prescott, L.M., J.P. Harley. \& D.A. Klein. 1999. Microbiology 4th ed. Mc-Graw Hill Comp, Inc. New York. USA

Ray, Bibek. 2005. Fundamental Food Microbiology: Third Edition. CRC Press: London

Tortura, G.J., Funke, B.R. dan Case, C.L. 2004. Microbiology. An Introduction. Menlo Park, CA.: The Benjamin/Cummings Publishing Company, Inc. 


\section{BAB VI \\ PANGAN FERMENTASI}

A. Definisi Pangan Fermentasi

Pangan fermentasi merupakan bahan pangan yang dihasilkan dari proses fermentasi. Dimana proses fermentasi merupakan proses pengolahan pangan dengan memanfaatkan mikroba untuk menghasilkan produk olahan baru yang memiliki karakteristik aroma dan flavor yang khas. Pada proses fermentasi akan ada pemecahan substrat oleh mikroba menghasilkan alkohol, karbondioksida, ataupun asam organik.

Ada beberapa keuntungan fermentasi dalam pengolahan pangan. Diantaranya adalah sebagai berikut:

- Menghasilkan produk makanan yang memiliki karakteristik flavor dan aroma yang khas.

- Memperkaya variasi makanan dengan mengubah aroma, rasa, dan tekstur.

- Dapat meningkatkan nilai gizi dari produk pangan yang dihasilkan. Contohnya adanya probiotik dari produk pangan hasil fermentasi. Selain itu, kita dapat juga menambahkan zat gizi tertentu seperti protein, asam amino, serta vitamin.

- Modal dan biaya dalam memproduksi pangan fermentasi cukup rendah. 
- Teknologi fermentasi secara umum sudah dikuasai oleh sebagian masyarakat secara turun menurun.

- Dapat memperpanjang umur simpan dari bahan pangan. Dikarenakan pada saat fermentasi akan dihasilkan sejumlah asam seperti asam laktat, asam asetat, dan alkohol. Asam-asam organik inilah yang membuat $\mathrm{pH}$ dari pangan fermentasi rendah sehingga dapat mencegah pertumbuhan mikroba.

B. Peran Mikroorganisme pada Produk Fermentasi

Berdasarkan produk yang dihasilkan pada proses fermentasi, fermentasi diklasifikasikan menjadi dua yaitu fermentasi homofermentatif dan fermentasi heterofermentatif.

1. Fermentasi Homofermentatif

Proses fermentasi dikatakan bersifat homofermentatif jika hanya menghasilkan satu jenis komponen saja sebagai hasil utamanya. Misalnya dari hasil fermentasi hanya menghasilkan asam laktat.

Contoh bahan pangan yang proses fermentasinya bersifat homofermentatif adalah yogurt, kefir, dan kombucha.

2. Fermentasi Heterofermentatif

Proses fermentasi dikatakan bersifat heterofermentatif jika menghasilkan campuran 
berbagai senyawa/komponen utama. Misalnya dari proses fermentasi selain dihasilkan asam laktat juga menghasilkan etanol.

Contoh bahan pangan yang proses fermentasinya bersifat heterofermentatif adalah tape dan fruit wine.

Berdasarkan penggunaan oksigen pada saat fermentasi, maka fermentasi dibagi menjadi dua yaitu fermentasi aerobik dan fermentasi anaerobik. Fermentasi aerobik merupakan proses fermentasi yang membutuhkan oksigen pada prosesnya sedangkan jika fermentasi tidak membutuhkan oksigen dalam prosesnya disebut fermentasi anaerobik. Secara umum proses fermentasi secara aerobik dan anaerobik dapat dilihat pada Gambar di bawah ini. 
Gula

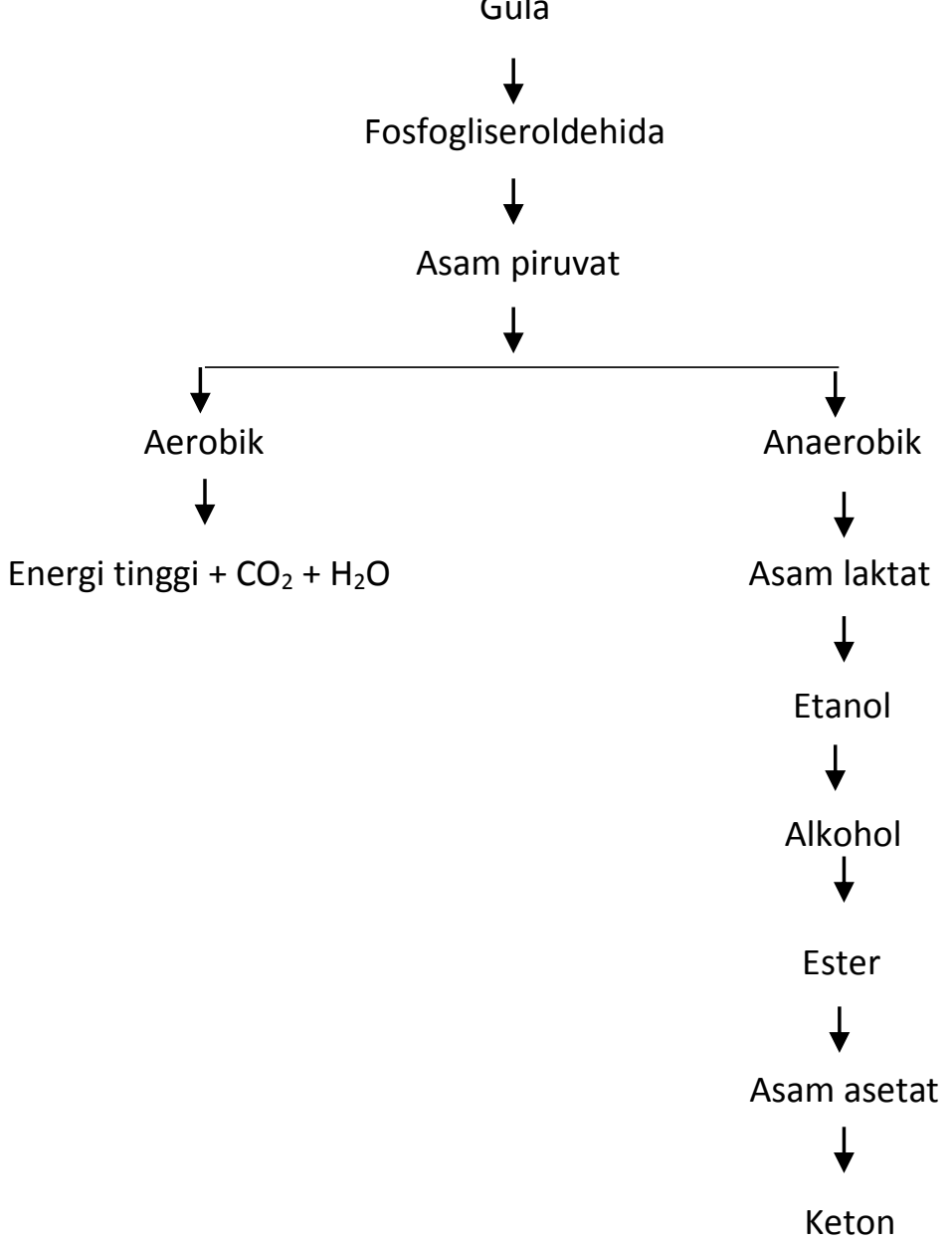

Penerapan metode fermentasi yang banyak digunakan diantaranya adalah fermentasi alkohol dan fermentasi asam laktat. Fermentasi alkohol dan 
fermentasi asam laktat memiliki perbedaan dalam produk akhir yang dihasilkan. Produk akhir fermentasi alkohol berupa etanol dan $\mathrm{CO}_{2}$, sedangkan produk akhir fermentasi asam laktat berupa asam laktat. Secara umum proses fermentasi asam laktat dan fermentasi alkohol dapat dilihat pada Gambar di bawah ini.

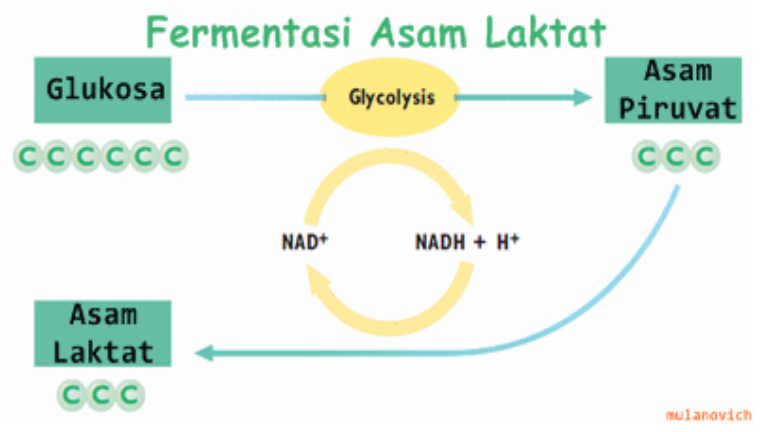

Fermentasi Alkohol

\section{Glukosa}

CCCCCC
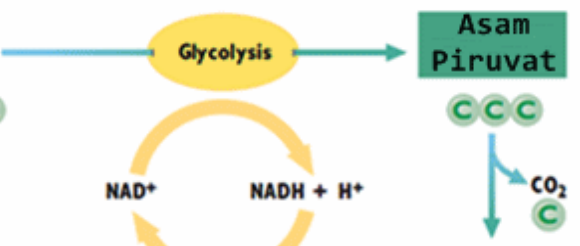

Etanol Asetaldehid CC C C

Contoh bahan pangan yang termasuk fermentasi asam laktat adalah pada fermentasi daging yaitu sosis, 
fermentasi sayuran yaitu sayur asin, dan keju. Sedangkan bahan pangan yang termasuk dalam fermentasi alkohol diantaranya adalah bir, tape, dan anggur.

Mikroba untuk fermentasi bahan pangan dapat berupa kultur murni maupun kultur campuran. Contoh kultur campuran adalah campuran bakteri, khamir maupun kapang. Mikroba yang digunakan untuk menghasilkan produk pangan tertentu dapat dilihat pada Tabel di bawah ini.

\begin{tabular}{ll}
\hline \multicolumn{1}{c}{ Produk } & \multicolumn{1}{c}{ Mikroba } \\
\hline $\begin{array}{l}\text { Bakery, bir, wine } \\
\text { probiotik } \\
\text { Soy sauce }\end{array}$ & $\begin{array}{l}\text { Saccharomyces cerevisiae } \\
\text { Bakteri Asam Laktat }\end{array}$ \\
& $\begin{array}{l}\text { Aspergillus oryzae, } \\
\text { Zygosaccharomyces, }\end{array}$ \\
Tempe & Rouxii \\
Tape & Hansenula, \\
& Saccharomyces \\
Asam asetat & Acetobacter aceti \\
Asam sitrat & Aspergillus niger \\
Asam laktat & Lactobacillus delbrueckii \\
Nata & Acetobacter xylinum \\
Acar, Asinan kubis & Bakteri Asam Laktat \\
Asam glutamat & Corynebacterium \\
Lisin & glutamicum \\
& Brevibacterium \\
& lactofermentum
\end{tabular}


Penisilin

Oncom Angkak
Penicillium chrysogenum

Neurospora sitophila

Monascus purpureus

C. Pangan Fermentasi

a. Tempe

Tempe adalah pangan fermentasi berbahan baku kedelai. Mikroba yang berperan dalam pembuatan tempe adalah Rhizopus oligosporus. Kedelai mempunyai bau khas langu. Dengan adanya proses fermentasi ini bau langu dari kedelai bisa dihilangkan. Fermentasi kedelai menjadi tempe akan meningkatkan kandungan fosfor. Hal ini disebabkan oleh hasil kerja enzim fitase yang dihasilkan kapang Rhizopus oligosporus yang mampu menghidrolisis asam fitat menjadi inositol dan fosfat yang bebas. Gambar produk tempe dapat dilihat pada Gambar di bawah ini.

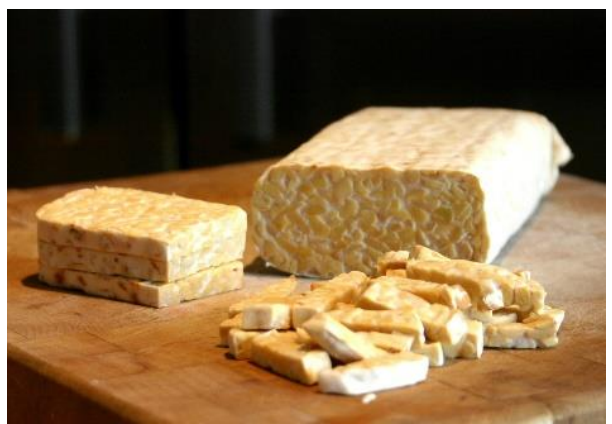

Tempe 
b. Tape

Tape merupakan pangan fermentasi yang melibatkan ragi, dengan bahan baku pangan karbohidrat tinggi dan sumber pati. Mikroorganisme yang terlibat dalam pembuatan tape diantaranya adalah Saccharomyces cerevisiae, Rhizopus oryzae, Endomycopsis burtonii, Mucor sp., Candida utilis, Saccharomycopsis fibuligera, Pediococcus, dll. Bahan baku pembuatan tape pada umumnya terbuat dari singkong dan ketan. Selain dari singkong dan ketan, tape juga bisa dibuat dari sumber karbohidrat lain seperti ubi jalar dan talas. Fermentasi tape dapat meningkatkan kandungan Vitamin B1 (tiamin) hingga tiga kali lipat.

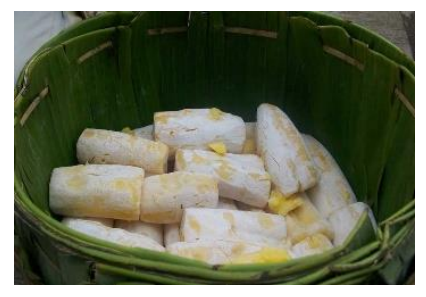

Tape singkong

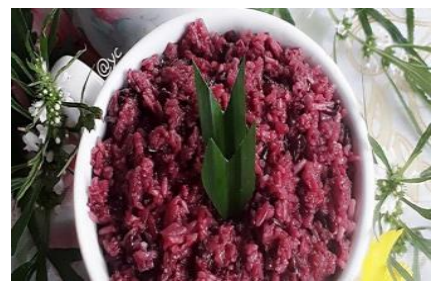

Tape ketan

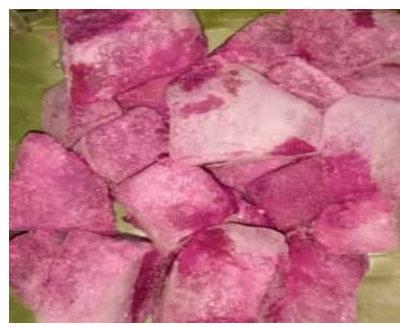

Tape ubi ungu 


\section{c. Yogurt}

Yogurt adalah pangan fermentasi berbahan baku susu. Mikroba yang berperan pada proses pembuatan yogurt adalah dari Bakteri Asam Laktat, yaitu Lactobacillus bulgaricus dan Streptococcus thermophillus. Proses fermentasi yoghurt akan merubah gula-gula yang ada di dalam susu, terutama laktosa menjadi asam laktat dan asam-asam lainnya. Asam laktat yang dihasilkan selama proses fermentasi dapat meningkatkan citarasa dan meningkatkan keasaman atau menurunkan pH-nya. Semakin rendahnya $\mathrm{pH}$ atau derajat keasaman susu setelah fermentasi akan menyebabkan semakin sedikitnya mikroba yang mampu bertahan hidup dan menghambat proses pertumbuhan mikroba patogen dan mikroba pembusuk, sehingga umur simpan susu dapat menjadi lebih lama.

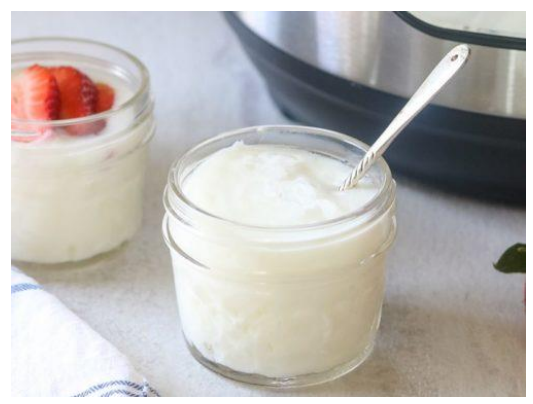

Yogurt 
d. Kefir

Kefir merupakan pangan fermentasi dari susu. Kefir mempunyai rasa, warna, dan rasa seperti yoghurt dengan aroma khas khamir (seperti tape). Starter yang digunakan pada proses pembuatan kefir berupa butir atau biji kefir. Biji kefir ini berbentuk buturan-butiran putih dari kumpulan bakteri Streptococcus sp., Lactobacillus, dan beberapa jenis ragi. Bakteri berperan dalam pembentukan asam laktat dan komponen flavour pada kefir. Sedangkan ragi berperan dalam pembentukan karbondioksida dan alkohol. Itulah sebabnya kefir mempunyai rasa asam dan ada sedikit rasa alkohol dan soda.

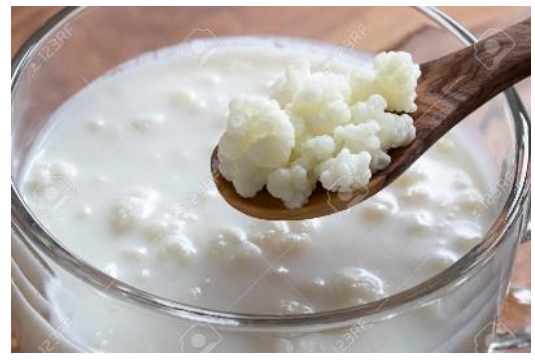

Kefir

e. Kombucha

Kombucha merupakan minuman fermentasi dari teh dan gula yang mempunyai rasa khas asam dan manis. Mikroba yang berperan dalam pembuatan kombucha adalah Acetobacter xylinum dan Saccharomuces cerevisiae. Proses fermentasi pada pembuatan kombucha diawali dengan 
pemecahan sukrosa menjadi glukosa dan fruktosa. Selanjutnya glukosa dan fruktosa dipecah menjadi asam-asam organik dan alkohol.

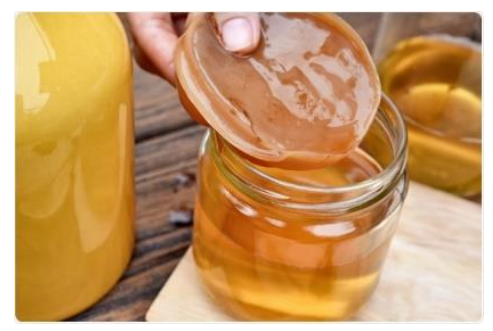

Kombucha

f. Oncom

Oncom merupakan salah satu produk fermentasi makanan khas Jawa Barat yang menggunakan substrat bungkil kacang tanah atau ampas tahu yang diinokulasi dengan spora kapang oncom merah, kapang yang berperan dalam proses fermentasi oncom merah (kapang oncom merah) adalah Neurospora sp. Kapang ini mudah tumbuh pada substrat, mempunyai waktu generasi yang pendek, dan miseliumnya terdiri dari hifa yang bercabang, menjulang ke udara, yang mudah dikenal dari kondisinya yang berwarna jingga.

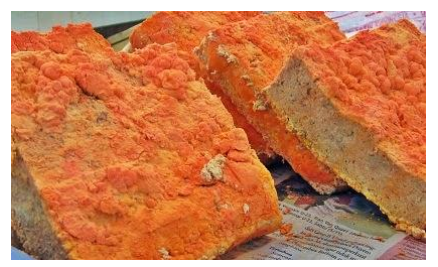

Oncom 


\section{g. Sayur Asin}

Sayur asin adalah pangan fermentasi oleh Bakteri Asam Laktat yang yang mempunyai cita rasa khas. Dalam proses fermentasi sayuran digunakan bakteri alami yang terdapat dalam sayur-sayuran, seperti sawi hijau, kubis, dsb. Jenis Bakteri Asam Laktat yang berperan dalam pembuatan sayur asin adalah Leuconostoc mesenteroide, Lactobacillus cucumeris, L. plantarum dan L. pentoaceticus. Fermentasi pada pembuatan sayur asin dilakukan dalam keadaan anaerob, adanya udara pada saat proses fermentasi akan mengakibatkan terjadinya proses pembusukan pada sayur asin.

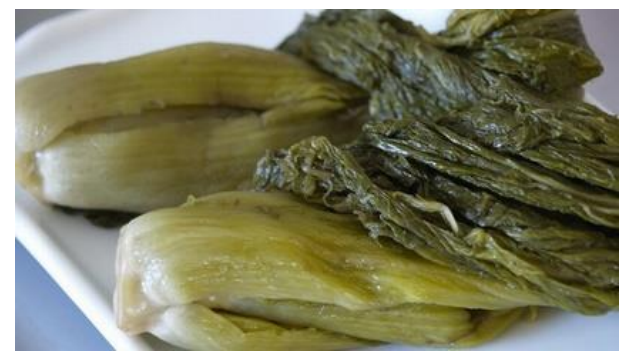

Sayur asin

h. Keju

Keju merupakan pangan fermentasi dari susu dengan memanfaatkan renet atau enzim proteolitik lainnya sehingga terjadi penggumpalan. Berdasarkan teksturnya keju dibedakan menjadi 
empat yaitu keju lunak, keju setengah lunak, keju keras dan keju sangat keras. Keju dikatakan lunak jika kadar air keju lebih besar dari 40\%, keju setengah lunak jika kadar air 36-40\%, keju keras yaitu keju dengan kadar air 25-36\% dan keju sangat keras mempunyai kadar air kurang dari $25 \%$.

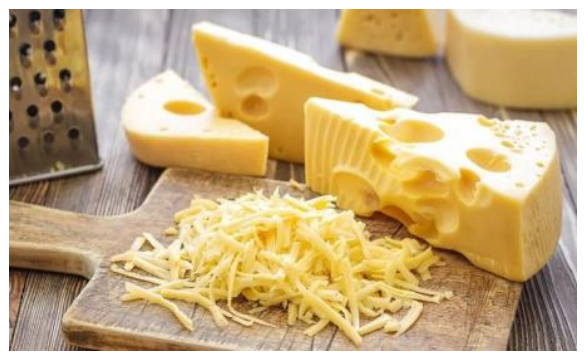

D. Kesimpulan

Keju

- Pangan fermentasi merupakan bahan pangan yang dihasilkan dari proses fermentasi.

- Pada proses fermentasi akan ada pemecahan substrat oleh mikroba menghasilkan alkohol, karbondioksida, ataupun asam organik.

- Berdasarkan produk yang dihasilkan pada proses fermentasi, fermentasi diklasifikasikan menjadi dua yaitu fermentasi homofermentatif dan fermentasi heterofermentatif.

- Berdasarkan penggunaan oksigen pada saat fermentasi, maka fermentasi dibagi menjadi dua yaitu fermentasi aerobik dan fermentasi anaerobik. 
- Produk akhir fermentasi alkohol berupa etanol dan $\mathrm{CO}_{2}$, sedangkan produk akhir fermentasi asam laktat berupa asam laktat.

- Mikroba untuk fermentasi bahan pangan dapat berupa kultur murni maupun kultur campuran.

- Contoh pangan fermentasi diantaranya adalah tempe, kefir, oncom, yogurt, kombucha, tape, sayur asin, dan masih banyak lagi yang lainnya.

E. Latihan Soal

1. Apa prinsip proses fermentasi pada bahan pangan?

2. Apa perbedaan antara fermentasi homofermentatif dan fermentasi heterofermentatif?

3. Mengapa produk pangan hasil fermentasi dapat memperpanjang masa simpan dari produk pangan tersebut?

4. Apa yang menyebabkan kegagalan pada pembuatan produk fermentasi?

5. Produk hasil fermentasi apa yang sering anda konsumsi sehari-hari? Mikroba apa yang berperan dalam pembuatan produk fermentasi tersebut? 


\section{Daftar Pustaka}

Adam,MR. 2001. Microbiology of Fermented Food. Elsivier Applied Science Publisher, Ltd. New York

Anshori, R. 1989. Pengantar Teknologi Fermentasi. Departemen Pendidikan dan Kebudayaan Direktorat Jenderal Perguruan Tinggi Pangan dan Gizi. Institut Pertanian Bogor: Bogor

Bachruddin, Z. 2014. Teknologi Fermentasi. Gadjah Muda University Press: Yogyakarta

Battcock M. dan S. Azam-Ali. 1998. Fermented Frutis and Vegetables: a global perspective. FAO Agri. Services Bul

Dyson, S. dan McShane, R. 2009. Fermented Food: The benefits and necessity of fermenting as a process. Food Article/commentary

Hui, Y. H., Meunier-Goddik, L., Hansen, Å. S., Josephsen, J., Stanfield, P. S., and Toldrá, F. 2004. Handbook of food and Beverage Fermentation Technology.Marcel Dekker, Inc. United States of America

Jay, J.M. 2000. Fermentation and fermented dairy products, pp. 113-130.In Modern Food Microbiology, 6th edition.An Aspen Publication, Aspen Publishers, Inc. Gaithersburg, USA

Riadi, Lieke. 2007. Teknologi Fermentasi. Yogyakarta : Graha IImu.

Said, E. G. 1987. Teknologi Fermentasi. CV Rajawali : Jakarta

Suprihatin. 2010. Teknologi Fermentasi. Penerbit UNESA University Press. 


\section{DAFTAR PUSTAKA}

Adam,MR. 2001. Microbiology of Fermented Food. Elsivier Applied Science Publisher,Ltd. New York

Adams, M. R. and Maurice O. M. 2008. Food Microbiology: Third Edition. RSC Publishing: UK

Anshori, R. 1989. Pengantar Teknologi Fermentasi. Departemen Pendidikan dan Kebudayaan Direktorat Jenderal Perguruan Tinggi Pangan dan Gizi. Institut Pertanian Bogor: Bogor

Bachruddin, Z. 2014. Teknologi Fermentasi. Gadjah Muda University Press: Yogyakarta

Battcock M. dan S. Azam-Ali. 1998. Fermented Frutis and Vegetables: a global perspective. FAO Agri. Services Bul

Cano, R.J. dan Colom, J.S. 1986. Microbiology. St. Paul, MN: West Publishing Company

Dwidjoseputro, D. 2003. Dasar - Dasar Mikrobiologi. Djambatan. Jakarta

Dyson, S. dan McShane, R. 2009. Fermented Food: The benefits and necessity of fermenting as a process. Food Article/commentary

Fardiaz, S. 1989. Mikrobiologi Pangan. Institut Pertanian Bogor, Bogor, Indonesia: Pusat Antar-Universitas Pangan dan Gizi 
Fardiaz, S. 1992. Mikrobiologi Pangan I. Gramedia Pustaka Utama. Jakarta

Frazier, W.C. dan Westhoff, D.C. 1979. Food Microbiology. New Delhi, India: Tata McGraw Hill Company, Ltd.

Gandjar, Indrawati dan Wellyzar, S. 2006. Mikrobiologi Dasar dan Terapan. Jakarta: Yayasan Obor Indonesia

Gupte, S. 1990. Mikrobiologi Dasar. Terjemahan E.Suryawidjaja : The Short Textbook of Medical Microbiology. Bina rupa Aksara. Jakarta

Hidayat, N. 2006. Mikrobiologi Industri. ANDI: Yogyakarta

Hui, Y. H., Meunier-Goddik, L., Hansen, Å. S., Josephsen, J., Stanfield, P. S., and Toldrá, F. 2004. Handbook of food and Beverage Fermentation Technology.Marcel Dekker, Inc. United States of America

Irianto, K. 2006. Mikrobiologi: Menguak Dunia Mikroorganisme Jilid 2. CV. Yrama Widya. Bandung

Jawetz, Melnick, dan Adelberg's. 2004. Mikrobiologi Kedokteran, Ed 23, Penerbit Buku Kedokteran EGC, Jakarta

Jay, J.M. 2000. Fermentation and fermented dairy products, pp. 113-130.In Modern Food Microbiology, 6th edition.An Aspen Publication, Aspen Publishers, Inc. Gaithersburg, USA 
Jay, J.M., Martin J.L., and David A.G. 2005. Modern Food Microbiology: Seventh Edition. Springer: United States of America

Lim, D. 1990. Microbiology. McGrow-Hill Book, New York

Lucke, F.K. 2000. Utilization of Microbes to Process and Preserve Meat. Meat Sci

Pelczar. J. Michael dan Chan E.C.S. 2006. Dasar-dasar Mikrobiologi. Universitas Indonesia : Jakarta

Prescott, L.M., J.P. Harley. \& D.A. Klein. 1999. Microbiology 4th ed. Mc-Graw Hill Comp, Inc. New York. USA

Purwoko,T. 2009. Fisiologi Mikroba. Bumi Aksara. Jakarta

Ray, Bibek. 2005. Fundamental Food Microbiology: Third Edition. CRC Press: London

Riadi, Lieke. 2007. Teknologi Fermentasi. Yogyakarta : Graha Ilmu.

Ryan, KJ; Ray, CG, eds. 2004. Sherris Medical Microbiology (4th ed.). McGraw Hill

Said, E. G. 1987. Teknologi Fermentasi. CV Rajawali : Jakarta

Sumarsih, S., 2003. Mikrobiologi Dasar. Universitas Pembangunan Nasional Veteran, Yogyakarta

Suprihatin. 2010. Teknologi Fermentasi. Penerbit UNESA University Press. 
Suriawiria U. 2005. Mikrobiologi Dasar. Jakarta : Papas Sinar Sinanti

Tortura, G.J., Funke, B.R. dan Case, C.L. 2004. Microbiology. An Introduction. Menlo Park, CA.: The Benjamin/Cummings Publishing Company, Inc. 


\section{BIODATA PENULIS}

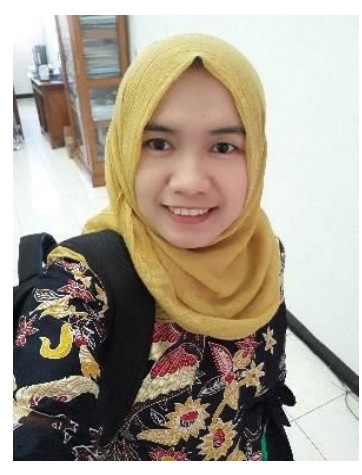

Rima Azara, S.TP, M.P. dilahirkan di Malang, 12 Januari 1990. Pendidikan dasar SD dan SMP diselesaikan di Wajak, Malang. Tahun 2008 penulis lulus dari SMA Negeri I Tumpang dan diterima di Universitas Brawijaya, Fakultas Teknologi Pertanian, Jurusan Ilmu dan Teknologi Pangan. Gelar Magister pada jurusan Teknologi Hasil Pertanian juga diperoleh di Universitas yang sama pada tahun 2013. Mulai tahun 2014 hingga sekarang, penulis menjadi dosen tetap di Universitas Muhammadiyah Sidoarjo. Matakuliah yang diampu penulis di prodi THP UMSIDA salah satunya adalah Mikrobiologi Pangan.

Ir. Ida Agustini Saidi, MP. lahir di Denpasar, Bali 4 Agustus 1959. Lulus Sarjana Pertanian Jurusan Agronomi Institut Pertanian Bogor tahun 1982, melanjutkan studi S2 di Prodi Teknologi Pasca Panen Program Pascasarjana Universitas Brawijaya lulus tahun 1997. Karir pengajaran dimulai tahun 1983 di Fakultas Pertanian Universitas Udayana, Denpasar, tahun 1991 hingga tahun 2002 di Fakultas Pertanian Universitas Bangkalan Madura dan selanjutnya hingga sekarang di Universitas Muhammadiyah Sidoarjo. 
